American Journal of Animal and Veterinary Sciences 4 (4): 108-128, 2009

ISSN 1557-4555

(C) 2009 Science Publications

\title{
Potential, Implications and Solutions Regarding the Use of Rendered Animal Fats in Aquafeeds
}

\author{
${ }^{1}$ Jesse T. Trushenski and ${ }^{2}$ Rebecca T. Lochmann \\ ${ }^{1}$ Fisheries and Illinois Aquaculture Center, Department of Zoology, \\ Southern Illinois University Carbondale, \\ 1125 Lincoln Drive, Life Science II, Room 173, Carbondale, IL 62901-6511 \\ ${ }^{2}$ Aquaculture/Fisheries Center, University of Arkansas at Pine Bluff, 1200 N, University Drive, \\ Mail Slot 4912, Pine Bluff, AR 71601
}

\begin{abstract}
Problem statement: In the past, aquafeeds were comprised largely of fish meal and fish oil derived from marine reduction fisheries. In addition to being highly palatable and readily digested by cultured fishes, these feedstuffs were historically inexpensive sources of protein, energy and essential nutrients. However, increasing cost and concerns over safety and sustainability have greatly incentivized the transition from fish meal and oil to alternative sources of protein and lipid for aquafeed formulation. Fish oil replacement is proving more difficult than originally anticipated, particularly for marine carnivorous species. Approach: If complete fish oil replacement is not a viable goal for fish nutritionists and aquafeed manufacturers, at a minimum, we must strive for judicious use of limited marine-derived resources. In the present review, we explore the opportunities of using rendered fats as alternatives to marine-derived fish oils in aquaculture feeds, beginning with a discussion of the products themselves before reviewing the most recent literature and concluding with a discussion of the future of these products in aquafeed formulations. Results: Rendered fats have not been as intensively evaluated in aquaculture nutrition as grain and oilseed-derived lipids, although a number of recent publications on the subject suggest increasing interest in the use of rendered products in aquafeeds. Conclusion: Poultry fat, beef tallow, pork lard and to a lesser extent, yellow/restaurant grease and catfish oil, have been investigated individually or in combination with other lipids in feeds for a broad range of cultured taxa with generally acceptable results.
\end{abstract}

Key words: Aquaculture, fish oil, alternative lipid, rendering, fatty acid, fish nutrition

\section{INTRODUCTION}

In the past, aquafeeds were comprised largely of products derived from marine reduction fisheries, i.e., fish meal and fish oil. In addition to being highly palatable and readily digested by cultured fishes, these feedstuffs were historically inexpensive sources of protein, energy and essential nutrients. However, in the face of growing demand and relatively static landings, the price of fish meal and oil has grown steadily since the mid-1980 $\mathrm{s}^{[1]}$. In addition to market volatility driven by seasonal and inter-annual variations in landings, the fish meal and oil market is also affected by fluctuations in the price of competing commodities such as soybean meal and oil. As global interest in biofuels began to drive the price of grains and oilseeds at the beginning of the 2000s, fish meal and fish oil prices skyrocketed. In
2000 , fish meal and oil were both marketed at roughly $\$ 400$ USD/MT; today, the price of fish meal is \$1200 USD/MT and fish oil is priced in excess of $\$ 1600$ $\mathrm{USD} / \mathrm{MT}^{[1]}$. Rising costs have been joined by the issues of sustainability and product safety in creating substantial incentives to reduce the use of marinederived feedstuffs in aquafeeds: Environmental advocates have long-criticized aquaculture's reliance on capture fisheries and the practice of "feeding fish to fish" ${ }^{2]}$ and recently fish meal and fish oil have been linked with elevated levels of environmental contaminants in farm-raised seafood ${ }^{[3-5]}$.

The need to identify alternative raw materials for the burgeoning aquafeed industry is clear, but advances have been slowed by the difficulties in finding suitable alternatives to fish meal and particularly fish oil. Fish oil contains high levels of long-chain polyunsaturated

Corresponding Author: Jesse T. Trushenski, Fisheries and Illinois Aquaculture Center, Department of Zoology, Southern Illinois University Carbondale, 1125 Lincoln Drive, Life Science II, Room 173, Carbondale, IL 62901-6511 Tel: 618/536-7761 Fax: 618/453-6095 
fatty acids (LC-PUFA, No. of carbons $\geq 20$, No. of double bonds $\geq 3$ ), such as 20:5n-3 (eicosapentaenoic acid, EPA) and 22:6n-3 (docosahexaenoic acid, DHA), which are known to have a positive impact on a variety of human health disorders and conditions and are required micronutrients for many finfishes. Excluding specialty oils derived from algal or fungal cultures, fish oil alternatives contain, at most, trace levels of these fatty acids. The Food and Agriculture Organization addressed this pitfall in the most recent State of World Fisheries and Aquaculture report, concluding that "...given the difficulty in replacing fish oils...it is clear that competition for fish oil is likely to be a more serious obstacle [than fish meal] for some sections of

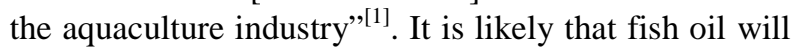
always been used in aquafeeds to some extent-complete replacement may be simply unattainable for some taxa or life stages ${ }^{[6]}$. If complete fish oil replacement is not a viable goal for fish nutritionists and aquafeed manufacturers, at a minimum, we must strive for judicious use of limited marine-derived resources. In the present study, we explore the opportunities of using rendered fats as alternative to marine-derived fish oils in aquaculture feeds, beginning with a discussion of the products themselves before reviewing the most recent literature. We revisit issues raised in a previous review of rendered fats in finfish nutrition ${ }^{[7]}$, providing the most up-to-date information available on the subject and conclude with a discussion of the future of these products in aquafeed formulations.

\section{Production and characteristics of rendered animal fats:}

Production of rendered animal fats: Rendering is the process by which waste animal tissues-usually from the slaughtering industry-are converted into more stable products of higher quality. Rendering produces protein meals and fats and the fats are often refined further to produce products such as tallow and lard. Rendering processes are distinct for "edible" and "inedible" products, which refers to the suitability of the products for human consumption. Fats produced by either process are suitable for inclusion in animal feeds, but the cost of the inedible grades is usually lower and they are more commonly used in fish feeds. The vast majority of rendered fats are from mammalian or avian sources, but in the Southern US, enough catfish offal oil is produced as a byproduct of the channel catfish industry to include in commercial feeds for catfish ${ }^{[8]}$. Other sources of rendered animal fats include mortalities of farmed animals, pets and zoo animals, as well as butcher trimmings and restaurant grease $\mathrm{s}^{[9]}$. On average, raw materials contain about $20 \%$ lipid before the rendering process. In 2005, 10.9 billion pounds of fat was produced by the US rendering industry. Inedible tallow, primarily from beef, accounted for more than one third ( 3.9 billion pounds) of the total ${ }^{[9]}$.

The rendering process for edible products is often conducted in a continuous, "wet" system, whereby ground raw materials are heated at a low temperature (with or without steam). The water and fat are separated from the solids by centrifugation and then a second centrifugation separates the water from the fat. Rendering for inedible products is usually a "dry" method in which the raw material is ground and heated to release fats and remove water. The free fat is recovered, then additional fat is pressed from the remaining solids to increase yield.

Lipid refinement: Crude lipids contain impurities such as phospholipids, free fatty acids, aldehydes, ketones, water and pigments. Various degrees of purification are applied to the crude lipids to improve quality and stability. Common purification processes include degumming, neutralization, bleaching and deodorizing. Degumming removes phospholipids and water, neutralization removes water and bleaching removes pigments, minerals, free fatty acids, aldehydes and ketones. Deodorizing removes free fatty acids and other compounds that cause objectionable flavors ${ }^{[10]}$. Winterizing-a common form of dewaxing-improves transparency, brightness and palatability of lipids. Not all of these refining processes are applied to inedible oils, which are the primary type used in animal feeds. However, stability is an important issue for feed manufacturers and lipids of low palatability can reduce feed intake and fish performance irrespective of the lipid's nutritional value. Nearly all rendered fats used in animal feeds are refined so that they are predominantly triglycerides, but they often contain free fatty acids and specifications now allow the addition of free fatty acids to the products. Triglycerides consist of a glycerol backbone esterified to three fatty acids, which may be essential or non-essential. The energy they liberate depends both on the carbon chain length and the degree of unsaturation of the fatty acids. Longer chains yield more energy than shorter chains and saturated chains (with no double bonds) yield more energy than unsaturated chains.

\section{Description of animal fats that have been used in fish diets: \\ Poultry fat: Obtained from the tissue of poultry in the commercial process of rendering or extracting, containing only the fatty matter natural to the product produced under good manufacturing practices.}


Lard: Fat rendered from fresh, clean, healthy tissues of swine.

Tallow (bovine or ovine): Product obtained by rendering the clean, sound, fatty tissues (including trimming and cutting fats), attendant muscles and bones of bovine animals and/or sheep in good health at the time of slaughter

Choice white grease: A specific grade of mostly pork fat.

Yellow grease: Recovered restaurant greases from deep fryers; may include tallow.

Catfish offal oil: Produced from the clean, dried and ground tissue and bones of fresh catfish parts, consisting primarily of heads, fins, viscera, skins, fillet frames and trim parts obtained from freshwater farmraised catfish in the US.

Menhaden fish oil: Oil extracted from fresh, whole menhaden in a wet reduction process.

Chemical and physical properties of fats used in fish diets: After rendered fats are produced and refined, their chemical and physical properties are characterized (Table 1). These features are used in manufacturing specifications, along with the fatty acid composition and can be used to determine the suitability of different lipids for different functions, including use as feedstuffs for animal diets. Lipid characteristics can also be used to determine whether a fat is pure, adulterated, or an intentional blend (such as an animal/vegetable blend).

Specific gravity is defined as the ratio of the density of a given solid or liquid substance to the density of water at a specific temperature and pressure. Different fats are very similar in specific gravity (Table 1). Viscosity is an internal property of a fluid that offers resistance to flow. Viscosity varies both among lipid types and with temperature. This property can have implications for feed manufacturing, as more viscous fats might slow the extrusion process. Color is measured using a variety of methods (Table 1). The FAC color is based on standards of the Fat Analysis Committee of the American Oil Chemists' Society (AOCS). FAC colors of 1-9 indicate light-colored fats, FAC 11-series colors are considered very yellow, FAC 13-19 indicates dark, reddish fat, FAC 21-29 are greenish fats and FAC 31-45 are very dark fats. Color can be influenced by diet, age, condition, geographical location and breed of the animal from which the fat is rendered. Although additives can be used to alter the color of rendered fats, this is not usually done to fats destined for use in livestock feeds. The MIU stands for moisture, impurities and unsaponifiable matter. Moisture should be less than $1 \%$ because higher levels can reduce the energy of the fat and cause oxidation. Impurities are non-hazardous materials that impede the filtering process during refining. Unsaponifiable matter (including sterols and pigments) does not convert chemically to soap and is low in available energy. The iodine value is a measure of the unsaturation of a lipid. Lipids with fatty acids containing more double bonds such as menhaden fish oil have higher iodine values,. Lipids with high iodine values typically have low melting points and titers (Table 1). The titer is the point at which a saponified fat resolidifies and is a measure of the "hardness" of a fat. Greases have titers below 40 and tallow has a titer above 40 . The melting point is the temperature at which a solid transitions to a liquid state. Some fats such as fish oils are liquid at room temperature $\left(25^{\circ} \mathrm{C}\right)$ and have melting points below that. Terrestrial animal fats are generally solid at room temperature and have higher melting points. Boiling point is defined as the temperature at which the vapor pressure of a liquid equals the environmental pressure surrounding the liquid. The boiling point of all fats is much higher than that of water $\left(100^{\circ} \mathrm{C}\right)$ and in some cases the lipids do not boil but decompose instead. Temperatures used in extrusion production of floating fish feeds are well below the boiling point of lipids.

Table 1: Chemical and physical characteristics of rendered animal fats

\begin{tabular}{|c|c|c|c|c|c|c|c|}
\hline Characteristic & Poultry fat & Lard & $\begin{array}{l}\text { Tallow (beef } \\
\text { or mutton) }\end{array}$ & Choice white grease & Yellow grease & $\begin{array}{l}\text { Catfish } \\
\text { offal oil }\end{array}$ & $\begin{array}{l}\text { Menhaden } \\
\text { fish oil }\end{array}$ \\
\hline Specific gravity, $15-15.6^{\circ} \mathrm{C}$ & 0.91 & 0.94 & $0.89-0.91$ & 0.84 & 0.92 & 0.8 & 0.92 \\
\hline $\begin{array}{l}\text { Viscosity, } 90-100^{\circ} \mathrm{C} \text { except } \\
\text { where noted } \\
(\mathrm{cSt}=\mathrm{cps}=\mathrm{mPas})\end{array}$ & 8.36 & 62.1 & 8.97 & $25\left(\right.$ at $\left.38^{\circ} \mathrm{C}\right)$ & 8.45 & $60\left(\right.$ at $\left.30^{\circ} \mathrm{C}\right)$ & 10 \\
\hline Color (various methods) & $\begin{array}{l}\text { Lt-brown } \\
\text { liquid/pale } \\
\text { brown solid }\end{array}$ & White & $\begin{array}{l}<3 \text { red (AOCS } \\
\text { Wesson) }\end{array}$ & $\begin{array}{l}\text { Yellow liquid/pale } \\
\text { brown solid; FAC } \\
\text { color 13-11B }\end{array}$ & $\begin{array}{l}\text { Med-brown liquid } \\
\text { /lt. brown solid; } \\
\text { FAC } 39 \text { (max) }\end{array}$ & $\begin{array}{l}\text { Light-medium } \\
\text { tan }\end{array}$ & 7 (Gardner) \\
\hline MIU (\%) & $1.3-2.8$ & 0.25 & 0.44 & 0.78 & $1.17-1.35$ & 1.10 & $\leq 0.5$ \\
\hline Iodine value (Wijs) & 83.9 & 57.6 & $3-50$ & $64-66$ & 104 & 89 & $\overline{172}$ \\
\hline Titer $\left({ }^{\circ} \mathrm{C}\right)$ & 34.98 & 38.0 & 42.40 & $36-37$ & 30.25 & $\mathrm{NR}^{1}$ & 32.0 \\
\hline Melting point $\left({ }^{\circ} \mathrm{C}\right)$ & 35.36 & $36-42$ & 44.72 & 32.5 & 33.87 & $<20$ & 13.0 \\
\hline Boiling point $\left({ }^{\circ} \mathrm{C}\right)$ & Decomposes & $<700$ & Decomposes & $<700$ & Decomposes & $>200$ & $>250$ \\
\hline Free fatty acids $(\%)$ & $15 \max$ & $15 \max$ & $10 \max$ & $15 \max$ & $5-10$ & $3-5$ & 0.2 \\
\hline Gross energy $\left(\mathrm{kcal} \mathrm{kg}^{-1}\right)$ & 9000 & 9020 & 9020 & 9350 & 9372 & $\mathrm{NR}^{1}$ & 9020 \\
\hline
\end{tabular}


American J. Animal \& Vet. Sci., 4 (4): 108-128, 2009

Table 2: Selected fatty acid composition (percent of total fatty acids by weight) of rendered animal fats ${ }^{1}$

\begin{tabular}{lllllllll}
\hline Fatty acids & $\begin{array}{l}\text { Poultry } \\
\text { fat }\end{array}$ & Lard & $\begin{array}{l}\text { Tallow } \\
\text { (beef) }\end{array}$ & $\begin{array}{l}\text { Tallow } \\
\text { (mutton) }\end{array}$ & $\begin{array}{l}\text { Choice white } \\
\text { grease }\end{array}$ & $\begin{array}{l}\text { Yellow } \\
\text { grease }\end{array}$ & $\begin{array}{l}\text { Catfish } \\
\text { offal oil }\end{array}$ & $\begin{array}{l}\text { Menhaden } \\
\text { fish oil }\end{array}$ \\
\hline $10: 0$ & ND & 0.1 & 0.1 & 0.2 & ND & ND & ND & ND \\
$12: 0$ & 0.2 & 0.2 & 0.1 & 0.3 & 0.1 & ND & ND & ND \\
$14: 0$ & 0.9 & 1.3 & 3.7 & 4.5 & 1.5 & 2.43 & 1.4 & 8.48 \\
$16: 0$ & 21.6 & 23.8 & 24.9 & 21.5 & 30.3 & 23.24 & 17.4 & 17.52 \\
$18: 0$ & 6.0 & 13.5 & 18.9 & 19.5 & 7.5 & 12.96 & 6.1 & 3.10 \\
SFA $^{2}$ & 27.5 & 39.2 & 47.5 & 46.0 & 39.4 & 38.60 & 24.9 & 29.10 \\
$14: 1$ & 0.2 & ND & 0.2 & 0.3 & ND & 0.20 & ND & ND \\
$16: 1$ & 6.4 & 2.7 & 4.2 & 2.3 & 3.7 & 3.97 & 2.9 & 11.51 \\
$18: 1^{3}$ & 37.3 & 41.2 & 36.0 & 37.6 & 46.0 & 44.32 & 49.1 & 9.52 \\
$22: 1$ & 0.1 & ND & ND & ND & ND & ND & ND & 0.67 \\
MUFA & 44.1 & 43.9 & 40.4 & 40.2 & 49.7 & 48.50 & 52.0 & 21.7 \\
$18: 2$ n-6 & 19.5 & 10.2 & 3.1 & 5.5 & 9.7 & 6.97 & 11.9 & 1.96 \\
$18: 3$ n-3 & 1.0 & 1.0 & 0.6 & 2.3 & 0.4 & 0.67 & 1.22 & 2.18 \\
$20: 4 n-6$ & 0.1 & ND & ND & ND & ND & ND & 4.5 & 2.55 \\
$20: 5$ n-3 & ND & ND & ND & ND & ND & ND & 0.99 & 12.73 \\
$22: 5$ n-3 & ND & ND & ND & ND & ND & ND & 0.97 & 2.78 \\
$22: 6$ n-3 & ND & ND & ND & ND & ND & ND & 1.09 & 12.31 \\
n-6 & 19.6 & 10.2 & 3.1 & 5.5 & 9.7 & 6.97 & 16.41 & 4.95 \\
n-3 & 1.0 & 1.0 & 0.6 & 2.3 & 0.4 & 0.67 & 4.27 & 33.3 \\
n-3 LC-PUFA & ND & ND & ND & ND & ND & ND & 3.05 & 27.82 \\
n-3/n-6 Ratio & 0.05 & 0.10 & 0.20 & 0.40 & 0.04 & 0.10 & 0.26 & 6.73 \\
Unsaturation Index $^{8}$ & 86.5 & 67.3 & 48.4 & 58.1 & 70.3 & 64.4 & 113.8 & 208.2 \\
\hline
\end{tabular}

${ }^{1}:$ Fatty acids present at $\leq 0.1 \mathrm{~g} / 100 \mathrm{~g}$ are not included in the table, ND $=$ not detected; ${ }^{2}:$ Saturated fatty acids, total of all fatty acids without double bonds; ${ }^{3}$ : Total of $\mathrm{n}-7$ and n-9 isomers; ${ }^{4}$ : Monounsaturated fatty acids, total of all fatty acids with a single double bond, includes $20: 1$ in addition to individually reported MUFA; ${ }^{5}$ : Total $n-6$ fatty acids, includes 20:3n-6 in addition to individually reported n-6 fatty acids; ${ }^{6}$ : Total n-3 fatty acids includes 18:4n-3 in addition to individually reported n-3 fatty acids; ${ }^{7}$ : Long-chain polyunsaturated fatty acids in the n-3 series, total of all fatty acids with chain length $\geq 20$ carbon atoms and double bonds $\geq 3 ;{ }^{8}$ : Unsaturation index $=\sum[$ (weight percent of unsaturated fatty acid $) \times($ number of double bonds)]

Free fatty acids in fats result from partial hydrolysis of the triglycerides during processing and sometimes storage prior to use in diets. The FFA value is expressed as a percentage of a fatty acid common to the product being tested, such as oleic acid for tallows. Aside from indicating instability or spoilage, free fatty acids (along with aldehydes, ketones and other compounds) are primary contributors to "off-flavors" and reduced palatability. Therefore, specifications on feed lipids usually list maximum allowable inclusion rates for free fatty acids. Rates up to $15 \%$ may be allowed in lower quality fats, but most contain from 1$10 \%$ (Table 1). Gross energy is a measure of the energy liberated when a fat is burned in a bomb calorimeter. All fats are concentrated energy sources and most feed fats are highly digestible by fish (see digestibility and utilization below). The addition of fats can also reduce fines associated with pelleted feeds as well as enhance flotation of extruded pellets.

Fatty acid composition: Rendered animal fats from mammalian and avian sources differ in fatty acid composition from one another and from fish oils (Table 2). None of the mammalian or avian sources contain the high concentrations of n-3 LC-PUFA found in marine fish oils (around 30\% 20:5n-3+22:6n-3).
Catfish offal oil contains more n-3 LC-PUFA than mammalian or avian fats, but less than marine fish oils. Marine fish oils also contain at least 3-fold more arachidonic acid (ARA, 20:4n-6) and approximately 5fold more cholesterol than other animal fats. However, many animal fats do contain significant amounts of $\mathrm{C}_{18}$ n-6 fatty acids (such as 18:2n-6) and low to moderate amounts of $\mathrm{C}_{18} \mathrm{n}-3$ fatty acids (such as $18: 3 \mathrm{n}-3$ ). There are other minor differences among the terrestrial animal fats. For instance, pure beef tallow differs from pure ovine (goat and sheep) tallow in that ovine tallow contains decanoic (10:0) and lauric (12:0) acids while beef tallow does not. These differences have little bearing on the energy content of lipids, which are all similar. There are numerous combinations of lipids that could meet the essential fatty acid requirements of different fish ${ }^{[11]}$ and provide energy. However, marine and carnivorous fishes generally require the n-3 LCPUFA found in highest concentrations in marine fish oils and terrestrial animal fats do not provide these. Some carnivorous fish perform well on diets with very little fish oil, but the n-3 LC-PUFA content and health value of the product for human consumers decline as a result of feeding low LC-PUFA feeds. Rendered animal fats from terrestrial sources can potentially be used at higher concentrations in diets of omnivorous or herbivorous fishes. 


\section{Lipid quality and stability-assessment and preservation: \\ Lipid decomposition: As soon as a fat is produced, it} begins to undergo a variety of chemical and physical changes. Lipid stability and quality can be compromised by factors such as moisture, heat, exposure to oxygen and exposure to metals or other damaging agents such as free radicals. The degree of unsaturation of a lipid is a major determinant of its tendency to oxidize or decompose. Unsaturated lipids contain double bonds that are targets for attack by free radicals, thus, highly unsaturated lipids such as marine fish oils are particularly vulnerable to attack. The byproducts of lipid oxidation, including peroxides and aldehydes, are associated with rancid flavors and aromas and can affect feed palatability and acceptance. Additionally, the oxidation process is progressive, with one free radical begetting another. Thus when added to a compound feed, rancid lipids can destroy vitamins and can affect the stability of proteins and carbohydrates.

There are a number of methods used to assess the integrity of lipids either before or after inclusion in feeds.

The AOM (Active Oxygen Method) predicts the stability of a fat by bubbling air through a solution of the fat using specific conditions of flow rate, temperature and concentration. At intervals, peroxides and hydroperoxides are measured by titration with iodine. The AOM value is defined as the number of hours required for the peroxide concentration to reach 100 meq $\mathrm{kg}^{-1}$ of fat. The more stable the fat, the longer it will take to reach that level. This method is still used, but is very slow for stable fats (up to $48 \mathrm{~h}$ ).

The Oxidative Stability Index (OSI) method is a more rapid, automated method to predict fat stability. Air is passed through a sample held at constant temperature, then bubbled through a reservoir of deionized water. Volatile acids produced by lipid oxidation are dissolved in the water, increasing its conductivity. Conductivity of the water is monitored continuously and the OSI value is defined as the hours required for the rate of conductivity change to reach a predetermined value.

In contrast to predictive methods, the Peroxide Value (PV), Anisidine Value (AnV) and the Thiobarbituric Acid Reactive Substances (TBARS) tests are used to assess the oxidation that has already occurred. Lipid decomposition is accompanied by characteristic compounds that appear at different stages of the process, or in different quantities depending on the severity of the decomposition ${ }^{[12]}$. Often, more than one test is used to determine the degree of lipid decomposition, because each test is fairly specific for compounds that appear at different stages of decomposition. For instance, peroxides appear early in the oxidation process, but they degrade into secondary products that are not detectable with a peroxide test. Therefore, the PV of a lipid tested after several months of exposure to harsh conditions (such as high temperature) could be just as low as the PV done on a fresh, high-quality product, obscuring the greater degree of oxidation in the more degraded product. It is thus difficult to correlate a specific PV with rancidity, but fresh fats have very low PV's of 1-2 and fats with PV of 15-20 are usually considered rancid.

The TBARS test specifically measures Malondialdehyde (MDA), another secondary decomposition product derived from polyunsaturated fatty acids. The MDA combines with thiobarbituric acid, yielding the TBARS. This is a well-established method for screening and monitoring lipid per oxidation. A higher TBARS number corresponds to a greater degree of rancidity. In general, oils with TBARS above $1.0 \mathrm{ppm}$ may be considered rancid.

The Anisidine Value (AnV) may be performed in conjunction with the PV test, because the AnV detects secondary products of lipid decomposition such as nonvolatile aldehydes (e.g., 2-alchene). High anisidine values may indicate lipid oxidation even when TBARS and other aldehyde tests give low results, because volatile aldehydes may be removed during processing. Anisidine value is defined as 100 times the absorbance (at $350 \mathrm{~nm}$ ) of a solution resulting from reaction of $1 \mathrm{~g}$ of fat in $100 \mathrm{~mL}$ of solvent. Choice white grease with an AnV of 10.6 was described as slightly rancid in one study ${ }^{[13]}$, but freshly produced peanut oil had a AnV of 20 in another study ${ }^{[14]}$. Therefore, it is difficult to compare the practical significance of AnVs among studies.

All of the methods of measuring lipid oxidation and rancidity have advantages and limitations due to the dynamic nature of the lipid decomposition process and the potential for interference by chemically similar products. Although more sophisticated tests are available to measure specific products of lipid peroxidation, they generally require expensive, sophisticated instrumentation (e.g., gas chromatograph/mass spectrophotometer) and may not be practical for routine quality control.

Antioxidant content: Both natural and synthetic compounds are used in feed lipids to prevent degradation due to chemical reactions with oxygen, or enzymatic reactions ${ }^{[15]}$. Although the FA composition of rendered fats make them more resistant to oxidation 
American J. Animal \& Vet. Sci., 4 (4): 108-128, 2009

than other, more unsaturated lipids, under unfavorable environmental conditions (i.e., high temperature, moisture, light, exposure to oxygen and metal salts) and in the absence of antioxidants, rancidity can develop. Rancid lipids have greatly reduced nutritional value and can compromise fish health and product quality ${ }^{[16-18]}$. Both fish tissues and most feed lipids contain vitamin $\mathrm{E}$ (tocopherols and tocotrienols) the primary fat-soluble antioxidant class in living cells. Vitamin $\mathrm{E}$ stored within the tissues will act to counteract free radicals ingested with rancid lipid until the vitamin E molecules themselves are depleted. If vitamin $\mathrm{E}$ stores are depleted and free radicals remain, the signs of vitamin E deficiency will manifest. These signs include fragile cell membranes, fluid accumulation in the abdomen (ascites), anemia, liver pathology, muscular dystrophy and reduced immune function ${ }^{[1,20]}$. Although animal tissues will contain vitamin $\mathrm{E}$ and other natural antioxidants (i.e., vitamin $\mathrm{C}$ and carotenoids), these compounds will be largely destroyed (by heat) or removed (i.e., by degumming or bleaching) during the rendering process. Accordingly, various antioxidants are added to rendered fats after processing to enhance stability and shelf-life. Although vitamin E is routinely added to fish feeds due to its essentiality as a vitamin, the form used most commonly is a synthetic racemic mixture of tocopherols in an esterified form (all-rac- $\alpha$ tocopheryl acetate), although esterified natural source vitamin E (RRR- $\alpha$-tocopheryl acetate) may also be used $^{[21,22]}$. The esterified tocopherol molecules are more light- and heat stable and thus preferred for extrusion applications, but these compounds have no antioxidant activity until consumed and converted back to the bioactive alcohol form via gastric hydrolysis. Therefore, to protect feeds and feedstuffs from oxidation during storage, other antioxidants may be used in place of, or more commonly in conjunction with vitamin E. Common synthetic antioxidants approved by the US Food and Drug Administration (FDA) for use in animal feeds include ethoxyquin (dehydroacetic acid), butylated hydroxyanisole (BHA) and butylated hydroxytoluene (BHT). These antioxidants protect lipids from oxidation during and after manufacturing, thus extending the shelf life of the feed. Recently, numerous reports of antioxidant activity in a variety of natural products (i.e., extracts of fruits, seeds, spices and teas) have surfaced ${ }^{[23]}$. The 'green revolution' would favor more natural ingredients in human foods and in animal feeds, but synthetic antioxidants are usually less expensive and more consistent in terms of potency. Given the sharp increase in cost of diets with standard ingredients since 2008, higher-cost natural antioxidants may be limited to use in diets of high- value species such as ornamentals and organicallyproduced fish and shellfish. Antioxidants are added to feed fats according to manufacturer or consumer specifications. The FAO Codex Standard for Named Animal Fats ${ }^{[24]}$ shows typical inclusion rates for various antioxidants.

Contaminant burden: Animal fats do not exhibit hazardous characteristics (i.e., flammable, combustible, corrosive, explosive or radioactive) and they have been designated as Generally Recognized As Safe (GRAS) feedstuffs by the FDA. Normally, there are no hazardous components in animal fats that are irritating, toxic or carcinogenic, however, if the source animals are exposed to environmental contaminants, these compounds can accumulate within the tissues and contaminate terrestrial rendered products ${ }^{[25]}$ in the same manner as rendered marine meal and oils. To assess the potential for contamination of livestock tissues with organic contaminants, the US Environmental Protection Agency and U.S. Department of Agriculture (USDA) conducted nationwide surveys of PCBs and dioxin-like compounds in pork, beef and poultry fats ${ }^{[26-28]}$. The results of these surveys indicated the range of contamination for the compounds assessed was less than $1 \mathrm{pg}^{-1}$ lipid (ppb) toxic equivalence concentrations (TEQ). These concentrations are quite low considering that Hazard Analysis and Critical Control Point plans specify FDA certification of levels below maximum tolerances in the $\mu \mathrm{g} \mathrm{g}^{-1}$ range (ppm). For example for DDT, DDD and DDE, $0.5 \mathrm{ppm}$; dieldrin, $0.3 \mathrm{ppm}$ and PCBs, $2.0 \mathrm{ppm}$. In addition, the FDA sets limits on heavy metals such as lead (7 ppm). The FAO codex has more stringent standards, with limits of $0.1 \mathrm{ppm}$ for lead or arsenic.

Production rates and cost of animal fats: Total production of selected animal fats in 2008, as well as current prices are shown in Table 3. Production of tallow exceeded that of all other rendered animal fats, followed closely by greases (Table 3). This pattern has been stable for decades. Poultry fats and lards are produced in smaller quantities, but their production is considered more sustainable than that of marine fish oils because the latter originate from wild fish. Catfish oil is not produced in large quantities compared to the other fats, but it could be a more sustainable source of essential fatty acids than menhaden oil, particularly for warm water fish raised in the southern US. The greater stability of catfish oil compared to menhaden oil is also attractive to feed producers, however, availability may become an issue as oil production has also decreased since 2008 due to significant declines in catfish production. 
American J. Animal \& Vet. Sci., 4 (4): 108-128, 2009

Table 3: Annual US production (2008) and current cost of rendered animal fats

\begin{tabular}{|c|c|c|c|c|c|c|c|}
\hline Item & Poultry fat & Lard & Tallow (beef or mutton) & Choice white grease & Yellow grease & Catfish offal oil & $\begin{array}{l}\text { Menhaden } \\
\text { fish oil }\end{array}$ \\
\hline $\begin{array}{l}\text { Production } \\
\text { (1000s of metric tons) }\end{array}$ & $500-600$ & $100-200$ & $16,000-17,000$ & $13,000^{1}$ & $\mathrm{NR}^{1}$ & 12.74 & 55.4 \\
\hline $\begin{array}{l}\text { Cents/pound in 2009, } \\
\text { to date }\end{array}$ & $25-30$ & $31-33$ & $23-28$ & $26-28$ & $23-27$ & 26 & $31-69$ \\
\hline
\end{tabular}

Although tallow supplies are strong, overall use in animal feeds has declined, possibly due to misguided concerns over Transmissible Spongiform Encephalopathies (TSEs) from animals fed ruminant products. There are no cases of humans or other animals contracting TSEs from fish and the infectious agents (prions) that cause TSEs are not present in rendered fats.

With the exception of fish oil, current prices of the other animal fats are similar. Prices for menhaden fish oil increased sharply in 2008 and early 2009, then declined. However, production is expected to decrease and the cost is likely to increase again in the near future. At the same time, there is a rapidly expanding market for fish oil for human nutritional supplements and functional foods that will increase competition for the limited supply of fish oil. As a result, there will be increasing pressure to reduce or eliminate marine fish oil from aquafeeds.

Increased use of poultry fat and lard in fish diets may be warranted if supplies are sufficient. However, there has been a global decrease in animal production since the onset of the economic crisis and supplies of all rendered animal fats may be restricted in the near future. Average prices for all terrestrial rendered fats have increased $20-30 \%$ since 2000 and prices typically increase as supplies dwindle. With increasing competition for many fats from the biofuels industry, the trends in supplies and costs are more difficult to predict. Nevertheless, rendered animal fats have considerable potential to replace most or all marine fish oil in fish diets due to their combination of nutritional qualities, reasonable costs and sustainable methods of production.

Using rendered animal fats in aquafeeds: Fish oil replacement is a broadly-researched theme in aquaculture nutrition and a wide variety of alternative lipids have been evaluated ${ }^{[29]}$. Rendered fats have not been as intensively evaluated as grain and oilseedderived lipids, although a number of recent publications on the subject seems to suggest increasing interest in the use of rendered products in aquafeeds. Poultry fat, beef tallow, pork lard and to a lesser extent, yellow/restaurant grease and catfish oil, have been investigated individually or in combination with other lipids in feeds for a broad range of cultured taxa (Table 4) with generally acceptable results.
Palatability and acceptance: Palatability and acceptance are not commonly reported to vary with dietary lipid source. Fish oil replacement is occasionally associated with changes in feed intake, however, this is mostly likely a consequence of altered nutrient density or digestibility of the feeds rather than diminished olfactory or gustatory response to the feeds themselves. Preference for certain flavors or feedstuffs is difficult to quantify in fishes, but the reason for reduced consumption can be inferred if the feed intake is expressed as a percent of body weight. If percent body weight consumed is reduced, one can assume palatability is an issue; if total consumption is reduced but percent body weight intake is unaffected, one can assume the issue is one of reduced digestibility/utilization resulting lower weight gain and a concomitant reduction in nutrient demand. That said, feed intake does not appear to be substantially affected by incorporation of rendered fats in aquafeeds. A vast majority of published studies report no effect whatsoever on feed intake, expressed as either cumulative intake or as a percent of body weight. Although Du et al. ${ }^{[30]}$ reported increased consumption of diets containing pork lard relative to fish oil-based feeds, when expressed as percent body weight, the differences in intake were minor (3.1 Vs 3.2\% BW/day for feeds containing $2 \%$ supplemental lipid). Yilmaz and Genc ${ }^{[31]}$ reported improved consumption of yellow grease-based diets by common carp, however, this was in comparison with diets containing soy acid oil, an apparently problematic dietary lipid source. YildirimAksoy et al. ${ }^{[32]}$ reported a reduction in cumulative consumption for Nile tilapia fed a beef tallow-based feed compared to a fish oil-based formulation. Although this was associated with a reduction in standardized feed intake as well, $(\sim 3.1$ Vs $\sim 2.4 \%$ $\mathrm{BW} /$ day), suggesting a greater preference for the fish oil feed, the authors attributed the reduction in intake to impaired digestibility and EFA deficiency. Regardless, as previously indicated, these effects are uncommonly reported and a wide variety of aquatic taxa accept rendered fat-based feeds readily. 
American J. Animal \& Vet. Sci., 4 (4): 108-128, 2009

Table 4: Summary of production performance effects of replacing dietary fish oil with rendered fats, expanded from Bureau et al. ${ }^{[7]}$

\begin{tabular}{|c|c|c|c|c|c|c|}
\hline \multirow[b]{2}{*}{ Species } & \multirow[b]{2}{*}{ Diet composition } & \multicolumn{5}{|c|}{ Effect of replacement on production performance criteria } \\
\hline & & Survival & Weight gain & Conversion efficiency & Consumption & Reference \\
\hline \multicolumn{7}{|l|}{ Warm-water Taxa } \\
\hline \multirow{21}{*}{$\begin{array}{l}\text { Channel catfish } \\
\text { Ictalurus punctatus }\end{array}$} & \multicolumn{2}{|l|}{$2.3 \%$ beef tallow +} & \multicolumn{3}{|c|}{$\uparrow$ (at higher temp) } & \multirow[t]{3}{*}{ [33] } \\
\hline & $2.3 \%$ corn oil $+2.3 \%$ & $=$ & \multirow{2}{*}{\multicolumn{3}{|c|}{$=($ at lower temp $)$}} & \\
\hline & Menhaden oil & & \multirow{2}{*}{\multicolumn{3}{|c|}{$\begin{array}{l}\downarrow \text { (at higher temp) } \\
=(\text { at lower temp })\end{array}$}} & \\
\hline & $7 \%$ beef tallow & $=$ & & & & [33] \\
\hline & $2.3 \%$ beef tallow + & & \multirow{3}{*}{\multicolumn{3}{|c|}{$\downarrow$}} & \multirow[t]{3}{*}{ [34] } \\
\hline & $2.3 \%$ corn oil $+2.3 \%$ & & & & & \\
\hline & Menhaden oil & & & & & \\
\hline & $7 \%$ beef tallow & & $\downarrow$ & & & [34] \\
\hline & $2 \%$ beef tallow & $=$ & $=$ & $=$ & & [97] \\
\hline & $2.3 \%$ beef tallow+ & & \multirow{3}{*}{\multicolumn{3}{|c|}{$\uparrow$}} & \multirow[t]{3}{*}{ [97] } \\
\hline & $2.3 \%$ corn oil $+2.3 \%$ & & & & & \\
\hline & Menhaden oil & & & & & \\
\hline & $7 \%$ beef tallow & & \multicolumn{3}{|l|}{$\downarrow$} & [97] \\
\hline & $2 \%$ beef tallow $(4.7 \%)$ & $=$ & \multirow{2}{*}{\multicolumn{3}{|c|}{$=$}} & [98] \\
\hline & $4 \%$ beef tallow $(6.7 \%)$ & $=$ & \multirow{2}{*}{\multicolumn{3}{|c|}{$\begin{array}{l}= \\
=\end{array}$}} & [98] \\
\hline & $2 \%$ catfish oil $(4.7 \%)$ & $=$ & & & & [98] \\
\hline & $4 \%$ catfish oil $(6.7 \%)$ & $=$ & $=$ & & & [98] \\
\hline & $\begin{array}{l}2 \% \text { poultry fat }+2 \% \\
\text { cod liver oil ( } 4 \% \text { lipid) }\end{array}$ & $=$ & $=$ & $=$ & & [99] \\
\hline & $4 \%$ poultry fat ( $4 \%$ lipid $)$ & $=$ & $=$ & $=$ & & [99] \\
\hline & $2 \%$ beef tallow ( $\sim \%$ lipid $)$ & $=$ & $=$ & $=$ & & {$[100]$} \\
\hline & $2 \%$ catfish oil ( $\sim \%$ lipid) & $=$ & $=$ & $=$ & & {$[100]$} \\
\hline Common carp & & & & & & \\
\hline Cyprinus carpio & $4.5 \%$ beef tallow $+5 \%$ feed oil & & $\downarrow$ & $=$ & $=$ & [101] \\
\hline & $9.5 \%$ beef tallow $+5 \%$ feed oil & & $\downarrow$ & $=$ & $\downarrow$ & [101] \\
\hline & $12 \%$ beef tallow $+1.4 \%$ & & $=$ & & & {$[102]$} \\
\hline & linseed oil & & & & & \\
\hline & 4,8 , or $13 \%$ yellow grease & $=$ & $\uparrow$ & $\uparrow$ & $\uparrow$ & [31] \\
\hline & $(4,8$, or $13 \%$ lipid $)$ & & Compared to so & cid oil & & \\
\hline African sharptooth cat & fish & & & & & \\
\hline Clarias gariepinus & $10 \%$ beef tallow & & $\downarrow$ Compared to s & flower oil & & [103] \\
\hline Blue tilapia & $2-14 \%$ beef tallow & & $=$ & $=$ & & [104] \\
\hline Tilapia aurea & (2-14\% crude lipid) & & & & & \\
\hline & $\begin{array}{l}2.5,5,7.5 \text {, or } 10 \% \text { catfish oil } \\
\text { (2.5-10\% lipid) }\end{array}$ & $=$ & $=$ & $=$ & & [105] \\
\hline Nile tilapia & $2.3 \%$ beef tallow & $=$ & $=$ & $=$ & $=$ & [32] \\
\hline Oreochromis niloticus & $+2.3 \%$ linseed oil & & & & & \\
\hline & $+2.3 \%$ corn oil ( $7 \%$ lipid) & & & & & \\
\hline & $\begin{array}{l}2.3 \% \text { beef tallow }+2.3 \% \text { corn } \\
\text { oil }+2.3 \% \text { fish oil }(7 \% \text { lipid })\end{array}$ & $=$ & $=$ & $=$ & $=$ & [32] \\
\hline & $7 \%$ beef tallow (7\% lipid) & $=$ & $\downarrow$ & $\downarrow$ & $\downarrow$ & [32] \\
\hline & $\begin{array}{l}4.9 \% \text { poultry fat }+4.9 \% \text { fish oil } \\
(9.8 \% \text { lipid })\end{array}$ & $=$ & $=$ & $=$ & $=$ & [93] \\
\hline $\begin{array}{l}\text { Hybrid tilapia } \\
\text { (blue } \times \text { nile) }\end{array}$ & $\begin{array}{l}1.7 \% \text { lard }+1.7 \% \text { corn oil } \\
+1.7 \% \text { cod liver oil }(5 \% \text { lipid })\end{array}$ & $=$ & $\uparrow$ & $\downarrow$ & & [106] \\
\hline & $\begin{array}{l}2.5 \% \text { lard }+2.5 \% \text { cod liver oil } \\
\text { (5\% lipid) }\end{array}$ & $=$ & $\downarrow$ & $\downarrow$ & & [106] \\
\hline & $\begin{array}{l}2.5 \% \text { lard }+2.5 \% \text { corn oil } \\
\text { (5\% lipid) }\end{array}$ & $=$ & $\downarrow$ & $\downarrow$ & & [106] \\
\hline & $5 \%$ lard (5\% lipid) & $=$ & $\downarrow$ & $\downarrow$ & & [106] \\
\hline & $8 \%$ lard (8\% lipid) & $=$ & $\downarrow$ & & & [107] \\
\hline Red drum & $5.4 \%$ beef tallow + & $=$ & $=$ & $=$ & & [79] \\
\hline Sciaenops ocellatus & $\begin{array}{l}1 \% \mathrm{n}-3 \text { HUFA mix } \\
(6.4 \% \text { lipid })\end{array}$ & & & & & \\
\hline Grass carp & 2,6 , or $10 \%$ pork lard & & $=($ at $2 \%$ lipid $)$ & $=($ at $2 \%$ lipid $)$ & (at $2 \%$ lipid) & {$[30]$} \\
\hline Ctenopharyngodon idella & $(2,6$, or $10 \%$ lipid $)$ & & $\uparrow$ (at 6 and & $\uparrow$ (at 6 and & $\uparrow$ (at 6 and & \\
\hline Fathead minnow & $10 \%$ poultry fat & $=$ & $\uparrow$ & $\uparrow$ & & [108] \\
\hline Pimephales promelas & (10\% lipid) & & & & & \\
\hline Golden shiner & $2 \%$ poultry fat $+2 \%$ cod liver oil & $=$ & $=$ & $=$ & & [99] \\
\hline Notemigonus crysoleucas & (4\% lipid) & & & & & \\
\hline & $4 \%$ poultry fat ( $4 \%$ lipid) & $=$ & $=$ & $=$ & & [99] \\
\hline Japanese sea bass & $5 \%$ beef tallow & $=$ & $=$ & $=$ & $=$ & [109] \\
\hline Lateolabrax japonicas & (10\% lipid) & & & & & \\
\hline
\end{tabular}


American J. Animal \& Vet. Sci., 4 (4): 108-128, 2009

\begin{tabular}{|c|c|c|c|c|c|c|}
\hline & $5 \%$ pork lard (10\% lipid) & $=$ & $=$ & $=$ & $=$ & [109] \\
\hline & $5 \%$ poultry fat ( $10 \%$ lipid) & $=$ & $=$ & $=$ & $=$ & [109] \\
\hline & $3 \%$ beef tallow $+1 \%$ & $=$ & $=$ & $=$ & $=$ & [109] \\
\hline & $\begin{array}{l}\text { Soy oil+1\% fish oil } \\
\text { (10\% lipid) }\end{array}$ & & & & & \\
\hline \multirow{3}{*}{$\begin{array}{l}\text { Largemouth bass } \\
\text { Micropterus salmoides }\end{array}$} & $5 \%$ chicken fat $+5 \%$ fish oil & $=$ & $=$ & $=$ & $=$ & [63] \\
\hline & (10\% lipid) & & & & & \\
\hline & $10 \%$ chicken fat ( $10 \%$ lipid) & $=$ & $=$ & $=$ & $=$ & [63] \\
\hline \multirow{5}{*}{$\begin{array}{l}\text { Surubim } \\
\text { Pseudoplatystoma } \\
\text { coruscans }\end{array}$} & $4 \%$ pork lard & $=$ & $=$ & $=$ & $=$ & [77] \\
\hline & $\begin{array}{l}+8 \% \text { squid liver oil } \\
(\sim 19 \% \text { lipid })\end{array}$ & & & & & \\
\hline & $\begin{array}{l}\text { 6\% pork lard }+6 \% \text { squid liver oil } \\
(\sim 19 \% \text { lipid })\end{array}$ & $=$ & $=$ & $=$ & $=$ & [77] \\
\hline & $\begin{array}{l}8 \% \text { pork lard }+4 \% \text { squid liver oil } \\
(\sim 19 \% \text { LIPID) }\end{array}$ & $=$ & $=$ & $=$ & $=$ & [77] \\
\hline & $12 \%$ pork lard ( 19\% lipid) & $=$ & $=$ & $=$ & $=$ & [77] \\
\hline \multicolumn{7}{|l|}{ Cool-water Taxa } \\
\hline \multirow{3}{*}{$\begin{array}{l}\text { White sturgeon } \\
\text { Acipenser transmontanus }\end{array}$} & $5 \%$ pork lard $+5 \%$ corn oil+ & $=$ & $=$ & $=$ & $=$ & [73] \\
\hline & $5 \%$ cod liver oil ( $15 \%$ lipid) & & & & & \\
\hline & $15 \%$ pork lard (15\% lipid) & $=$ & $=$ & $=$ & $=$ & [73] \\
\hline \multirow{3}{*}{$\begin{array}{l}\text { Hybrid striped bass } \\
\text { Morone chrysops } \\
\times \text { M. saxatilis }\end{array}$} & $4.9 \%$ poultry fat & $=$ & $=$ & $=$ & $=$ & [80] \\
\hline & $\begin{array}{l}+4.9 \% \text { fish oil } \\
\text { (9.8\% lipid) }\end{array}$ & & & & & \\
\hline & $2.5 \%$ catfish oil ( $2.5 \%$ lipid $)$ & $=$ & $=$ & $=$ & & [110] \\
\hline \multicolumn{7}{|l|}{ Cold-water Taxa } \\
\hline \multirow[t]{13}{*}{$\begin{array}{l}\text { Rainbow trout } \\
\text { Oncorhynchus mykiss }\end{array}$} & $\begin{array}{l}4 \% \text { hydrogenated beef } \\
\text { tallow }+6 \% \text { cuttlefish liver oil } \\
(10 \% \text { lipid })\end{array}$ & $=$ & $=$ & $=$ & & [111] \\
\hline & $6 \%$ hydrogenated beef tallow+ & - & - & $=$ & & {$[111]$} \\
\hline & $\begin{array}{l}10 \% \text { hydrogenated beef tallow } \\
(10 \% \text { lipid) }\end{array}$ & $=$ & $\bar{\downarrow}$ & $\bar{\downarrow}$ & & [111] \\
\hline & $\begin{array}{l}4.8 \% \text { lard }+7.2 \% \text { beef tallow } \\
\text { (18\% lipid) }\end{array}$ & & $\downarrow$ & & & [7] \\
\hline & $6 \%$ chicken fat (13\% lipid) & & $=$ & $=$ & & [112] \\
\hline & $6 \%$ pork lard (13\% lipid) & & $=$ & $=$ & & [112] \\
\hline & $6 \%$ beef tallow ( $13 \%$ lipid) & & $=$ & $=$ & & [112] \\
\hline & $\begin{array}{l}8 \% \text { beef tallow }+8 \% \text { fish oil } \\
\text { ( } 21 \% \text { lipid) }\end{array}$ & $=$ & $=$ & $=$ & & [7] \\
\hline & $\begin{array}{l}8 \% \text { beef tallow }+8 \% \text { herring oil } \\
(18 \% \text { lipid })\end{array}$ & $=$ & $=$ & & & [7] \\
\hline & $\begin{array}{l}8 \% \text { beef tallow }+8 \% \text { fish oil } \\
\text { (16\% lipid) }\end{array}$ & & $=$ & $=$ & $=$ & [36] \\
\hline & $8 \%$ beef tallow $+8 \%$ & & & & & \\
\hline & Alkitol omega-3 (16\% lipid) & & $=$ & $=$ & $=$ & [36] \\
\hline & $\begin{array}{l}10.2 \% \text { poultry fat }+5 \% \text { fish oil } \\
(15.2 \% \text { lipid })\end{array}$ & $=$ & $=$ & $=$ & $=$ & [94] \\
\hline \multirow{6}{*}{$\begin{array}{l}\text { Coho salmon } \\
\text { Oncorhynchus kisutch }\end{array}$} & $4 \%$ beef tallow $+12 \%$ salmon oil & & $=$ & & & [113] \\
\hline & $\begin{array}{l}8 \% \text { beef tallow }+8 \% \text { salmon oil } \\
\text { (16\% lipid) }\end{array}$ & & $=$ & & & [113] \\
\hline & $\begin{array}{l}12 \% \text { beef tallow }+4 \% \text { salmon oil } \\
\text { (16\% lipid) }\end{array}$ & & $\downarrow$ & & & [113] \\
\hline & $\begin{array}{l}4.3 \% \text { lard }+4.3 \% \text { canola oil } \\
\text { (12\% lipid) }\end{array}$ & $=$ & $=$ & $=$ & & [114] \\
\hline & $\begin{array}{l}4.3 \% \text { lard }+4.3 \% \text { herring oil } \\
\text { (12\% lipid) }\end{array}$ & $=$ & $=$ & $=$ & & [114] \\
\hline & $8.6 \%$ lard (12\% lipid) & $=$ & $=$ & $=$ & & [114] \\
\hline \multirow[t]{5}{*}{$\begin{array}{l}\text { Chinook salmon } \\
\text { oncorhynchus } \\
\text { tshawytscha }\end{array}$} & $\begin{array}{l}3 \% \text { beef suet }+1.5 \% \text { linseed oil } \\
+3.5 \% \text { salmon oil } \\
(15 \% \text { lipid })\end{array}$ & & $=$ & $=$ & & [115] \\
\hline & $\begin{array}{l}5 \% \text { beef suet }+3 \% \text { linseed oil } \\
\text { (15\% lipid) }\end{array}$ & & $=$ & $=$ & & [115] \\
\hline & $\begin{array}{l}6.5 \% \text { beef suet }+1.5 \% \text { linseed oil } \\
\text { (15\% lipid) }\end{array}$ & & $=$ & $=$ & & [115] \\
\hline & $\begin{array}{l}4.1 \% \text { lard }+4.1 \% \text { canola oil } \\
\text { (16\% lipid) }\end{array}$ & & $=$ & $=$ & & [116] \\
\hline & $\begin{array}{l}4.1 \% \text { lard }+4.1 \% \text { herring oil } \\
\text { (16\% lipid) }\end{array}$ & & $=$ & $=$ & & [116] \\
\hline
\end{tabular}


American J. Animal \& Vet. Sci., 4 (4): 108-128, 2009

\begin{tabular}{|c|c|c|c|c|c|c|}
\hline \multirow{6}{*}{$\begin{array}{l}\text { Atlantic salmon } \\
\text { Salmo salar }\end{array}$} & $8.2 \%$ lard (16\% lipid) & & $=$ & $=$ & & [116] \\
\hline & $\begin{array}{l}5 \% \text { beef tallow }+1.9 \% \text { herring oil } \\
\text { ( } 20 \% \text { lipid) }\end{array}$ & & $=$ & $=$ & & [117] \\
\hline & $\begin{array}{l}4.5 \% \text { lard }+3.5 \% \text { corn oil+ } \\
1 \% \text { canning oil ( } 9 \% \text { lipid) }\end{array}$ & & $=$ & & & {$[118]$} \\
\hline & $\begin{array}{l}40-50 \% \text { of total lipid as poultry fat } \\
\text { (dietary lipid increased during the } \\
\text { trial from } \sim 30 \text { to } \sim 37 \% \text { lipid) }\end{array}$ & & $=$ & $=$ & $=$ & [119] \\
\hline & $\begin{array}{l}3.5 \% \text { poultry fat }+3.5 \% \\
\text { canola oil }+16.5 \% \text { anchovy oil } \\
(23.5 \% \text { lipid })\end{array}$ & $=$ & $=$ & $=$ & $=$ & [74] \\
\hline & $\begin{array}{l}7 \% \text { poultry fat }+7 \% \text { canola oil } \\
+9.5 \% \text { anchovy oil } \\
\text { ( } 23.5 \% \text { lipid) }\end{array}$ & $=$ & $=$ & $=$ & $=$ & [74] \\
\hline \multirow{3}{*}{$\begin{array}{l}\text { Brown trout } \\
\text { Salmo trutta }\end{array}$} & $10.3 \%$ pork lard & $=$ & $=$ & $=$ & $=$ & [70] \\
\hline & (20\% lipid) & & & & & \\
\hline & $10.3 \%$ poultry fat ( $20 \%$ lipid) & $=$ & $=$ & $=$ & $=$ & [70] \\
\hline
\end{tabular}

Note: $\downarrow$ : Decrease relative to fish oil-based control feed, except where noted; $\uparrow:$ Increase relative to fish oil-based control feed, except where noted

Digestibility and utilization: The digestive system of finishes is apparently robust to a wide range of dietary lipids, however, most taxa conform to broad conventions with respect to digestion and absorption of different lipid and FA classes. The ability of finfish to digest and utilize lipids is a function of the physical state of the lipid source (liquid or solid at environmental temperature), the structural form of the lipid (waxes, sterols, phospholipids and triglycerols) and its fatty acid composition, as well as the innate digestive capacity of the taxon considered (gut morphology and enzyme activities).

Although fishes undoubtedly regulate their body temperature (i.e., through behavior), as poikilotherms, their body temperatures will fluctuate more so than their homeothermic, terrestrial counterparts. Although adaptations to broader temperature ranges have developed (i.e., enzymes with broad thermal ranges of activity, isozymes with disparate thermal optima), this does not compensate for the effect of different temperatures on the physical state of digesta. In other words, a lipid which is in a liquid state within the gastrointestinal tract of a homeotherm may solidify in the gut of cool or cold-water species. Because of their high polyunsaturated FA (PUFA, No. of double bonds $\geq 2$ ) content, most vegetable oils have freezing points below the ideal thermal range for most cultured fishes. Rendered fats, on the other hand, have much higher freezing points because of their predominantly saturated and monounsaturated fatty acid profile. These fats, particularly tallows and lards, may remain solid at normal culture temperatures, even for warm-water species (Table 1). As most chemical and enzymatic digestive processes are a function of surface area, solidification may dramatically impact digestibility as well as absorption of lipid. Although in one study, implementation of beef tallow in channel catfish feeds reduced weight gain regardless of fish oil replacement level ${ }^{[33]}$, in a later study, reduced growth was noted at lower temperatures ${ }^{[34]}$. Conversely, channel catfish reared at cooler temperatures grew equally well on feeds containing menhaden or catfish oils, but at warmer temperatures, the menhaden fish oil-fed group outperformed the catfish oil-fed group ${ }^{[35]}$. It is somewhat surprising that these effects were observed in a warm-water species-one might anticipate that the influence of temperature on lipid digestibility would be more pronounced in cool-and coldwater species whose ideal water temperatures are nearer or below the melting points of many rendered fats. On the other hand, one could hypothesize that the digestive systems of these species compensate morphologically (greater surface area, particularly within the pyloric ceca) or enzymatically (lower thermal optima, greater enzyme activity or production) for the effects of temperature on lipid digestibility. The latter appears to be true: Although dry matter digestibility of a beef-tallow based feed was slightly improved among rainbow trout reared at $15^{\circ} \mathrm{C}$ compared to $7.5^{\circ} \mathrm{C}$ (apparent digestibility coefficient $[\mathrm{ADC}]=82 \mathrm{Vs} 79)$, lipid digestibility was unaffected by temperature (ADC for $7.5^{\circ} \mathrm{C}=94, \mathrm{ADC}$ for $\left.15^{\circ} \mathrm{C}=95\right)^{[36]}$. Although lipid solidification within the gut may impact digestibility and utilization, the available data suggest the potential influence of temperature on digestibility of rendered fats is not particularly problematic.

Lipid digestibility and utilization are also affected by fatty acid and lipid class composition. The apparent digestibility of phospholipids and wax esters is less than that of triglycerols ${ }^{[37,38]}$ and in terms of digestion rates, triglycerols > cholesteryl esters > phospholipids ${ }^{[39]}$. Although perhaps less digestible than triglycerols, dietary phospholipid is nonetheless important for meeting dietary requirements for this nutrient class and 
for enhancing lipid digestion and absorption via the emulsifying action of the byproducts of phospholipid hydrolysis $^{[40]}$.

It has been suggested that polyunsaturated fatty acids are preferentially hydrolyzed within the gut ${ }^{[39]}$ and fatty acid uptake by enterocytes increases with chainlength and degree of unsaturation ${ }^{[41,42]}$. Based on these data, it follows that the digestibility of PUFA would be greater than monounsaturated FA (MUFA, No. of double bonds $=1$ ) and Saturated FA (SFA, No. of double bonds $=0)^{[38,43-45]}$, however, higher digestibilities of MUFA and SFA have also been observed $^{[46,47]}$. Turchini et al. ${ }^{[48]}$ and Francis et al. ${ }^{[4]}$ also observed the digestibility and absorption of PUFA $>$ MUFA $>$ SFA, but included the negative effect of increasing chain length as a caveat. In these studies, apparent digestibility coefficients were typically in the $\sim 85-95 \%$ range, though lower values $(\sim 65-75 \%)$ were noted for SFA, particularly for longer chain lengths and at lower temperatures. Although it would appear that the relative digestibility of fatty acids and fatty acid classes is controversial, given the variation in culture conditions, taxa and dietary formulations represented by these studies, it is perhaps not surprising that the digestibility values do not always agree. Furthermore, as discussed by Bureau et al. ${ }^{[7]}$, the digestibility of SFA may be enhanced by the presence of PUFA and/or MUFA. This appears to be the case: Digestibility of SFA was relatively high $(\sim 75-90 \%)$ when dietary PUFA levels were high ${ }^{[38,47]}$, whereas the digestibility coefficients for SFA declined sharply when dietary PUFA content was reduced ${ }^{[45]}$. Utilization of FA for energy production appears to follow a more predictable path. Generally, fish utilize SFA $>$ MUFA $>$ PUFA for energy production via $\beta$-oxidation ${ }^{[50-53]}$, although surpluses of PUFA and may increase shunting of these FA into catabolic pathways ${ }^{[54,55]}$.

From these studies, we can conclude that lipid digestion, absorption and fulfillment of energy requirements would be maximized by provision of SFA and MUFA-rich triglycerols, with sufficient amounts of phospholipid and PUFA to meet requirements and facilitate digestion and utilization. From this perspective, rendered fats would seem to be relatively well-suited for use in aquafeeds. Rendered fats contain substantial amounts of SFA, MUFA and PUFA (Table 2), primarily in the form of triglycerols. The expectation that rendered fats would be well-utilized by finfish appears to be borne out in the literature evaluating the use of rendered fats in aquafeeds. In general, rendered lipid-based feeds yield equivalent growth performance to that of fish oil-based feeds (Table 4). Reduced growth performance has been reported, however, in a majority of these cases, EFA deficiencies are likely to be contributing factors. Although PL may be a limiting factor for some rendered lipids, it is possible that supplementation with soy lecithin or other phospholipid-rich products may correct for reductions in overall lipid digestion and uptake.

Survival and growth performance: Survival does not appear to be impacted by incorporation of rendered fats in lieu of fish oil: of the studies reporting survival data, none demonstrated a significant effect of rendered fat source or dietary incorporation level. Though many of these studies were perhaps too short to allow nutritional deficiencies to develop and associated mortalities to occur, in most cases, the dietary formulations were not particularly aggressive with respect to known EFA requirements: i.e., most feeds still contained some basal amount of fish oil and intact LC-PUFA. Although survival encompasses many factors and is not necessarily responsive enough to characterize the nutritional sufficiency of a diet, particularly during the course of a short-term feeding trial, it is, of course, an important contributor to the "bottom line" of any aquaculture operation. The absence of differential mortality in these studies is encouraging and in keeping with complementary studies of plant-derived lipids.

As is the case with survival, growth performance is not typically affected by changes in dietary lipid source, so long as any basal energy and fatty acid requirements are met. Weight gain and conversion efficiency has been assessed for a wide variety of taxa fed diets containing various levels and blends of rendered fats. The results of these studies are summarized in Table 4 and overwhelmingly indicate partial, if not complete, replacement of marine-derived lipid with rendered fats is feasible for a wide range of finfishes.

Comparative physiological effects: A number of studies have been conducted to address the possible link between dietary lipid source and the immune system of fishes. Obviously, requirements for energy and essential fatty acids must be met to ensure normal immune function, however, dietary lipid content and composition may have immunological influence beyond basic nutritive value. Dietary lipid source may affect immunocompetence via two primary mechanisms: (1) by affecting membrane fatty acid composition and therefore fluidity, flexibility and function and/or (2) by affecting the inflammatory process and other cell-signaling pathways. Membrane strength and flexibility likely influence the ability of immunocompetent cells such as macrophages to phagocytose and destroy foreign cells and diet-related 
changes in lymphocyte membrane composition has been linked to impaired phagocytic function ${ }^{[56]}$. As a biosynthetic precursor to the physiologically potent eicosanoids (2-series prostanoids and 4-series leukotrienes), ARA has emerged as being particularly relevant to immunonutrition of aquatic and other species $^{[57]}$. In addition to absolute ARA levels, the balance between ARA and EPA (precursor to the lesspotent eicosanoids, 3-series prostanoids and 5-series leukotrienes) in the tissues appears to influence physiological status in aquatic species. Given the relationship between dietary FA composition and tissue profile, it is not surprising that replacing fish oil with various plant-derived lipids influences eicosanoid production $^{[58]}$ and, in turn, processes regulated by eicosanoids such as immune function ${ }^{[56,59-61]}$. However, most of these studies, in spite of having compared feeds with radically different fatty acid profiles, have reported moderate or conflicting immunological effects. Although there would appear to be a relationship between dietary lipid composition and immune function and disease resistance in fishes, the relationship is apparently indirect and nuanced.

Studies of the immunological effects of replacing fish oil with rendered fats have been similarly inconclusive. Feeding pork lard or poultry fat to vundu Heterobranchus longifilis resulted in significant alterations of various hematological parameters compared to fish raised on cod liver oil-based feeds ${ }^{[62]}$. In the poultry fat group, circulating red and white blood cell densities were significantly elevated, as was hemoglobin content; the pork lard group was largely unaffected with respect to these response parameters. Numbers of circulating platelets and lymphocytes and mean corpuscular volume (larger red blood cells) were significantly elevated in both rendered fat groups, whereas neutrophils were reduced relative to control. The authors interpreted these results as indicative of an inability of vundu to effectively utilize n-3 LC-PUFA and an immunosuppressive effect of cod liver oil via attenuation of the inflammatory response in these fish (i.e., eicosanoid derivatives of n-3 LC-PUFA tend to be anti-inflammatory). Conversely, one could argue that the altered hematological profiles and serum enzyme activities suggest the rendered fat groups were undergoing some sort of physiological challenge. The authors also noted significant elevation in serum alanine aminotransferase (in both the poultry fat and pork lard-fed groups) and aspartate aminotransferase (in pork lard-fed group only), which may be indicative of hepatic cellular degradation related to LC-PUFA deficiency in these fish. Nonetheless, the authors concluded that all of the observed effects of FO replacement were relatively mild and that all of the lipids evaluated were suitable for use in vundu feeds.

Lingenfelser et $a l^{[35]}$ assessed a suite of immunological parameters in channel catfish reared on menhaden fish oil- or catfish oil-based feeds at either 18 or $28^{\circ} \mathrm{C}$, before and after vaccination for Edwardsiella ictaluri. Although diet did not influence antibody production, cell-mediated immune responses were influenced by diet and temperature. Whereas macrophage phagocytic activity was greater among the catfish oil-fed fish at $28^{\circ} \mathrm{C}$, activity was greater in the menhaden oil-fed fish at $18^{\circ} \mathrm{C}$; respiratory burst activity was consistently greater in the menhaden-oil fed group. The authors attributed these responses to differences in cell membrane fatty acid composition and fluidity. As did Babalola and colleagues ${ }^{[62]}$, Lingenfelser et al. ${ }^{[35]}$ ultimately concluded that menhaden oil could be partially replaced by catfish oil in channel catfish feeds, at least at optimal culture temperatures, in spite of the immunological differences observed. Similarly, Subhadra et al. ${ }^{[63]}$ observed a reduction in complement activity (alternative activation pathway) and some changes in thrombocyte and lymphocyte counts in largemouth bass fed poultry fat-based feeds, but concluded these effects did not necessarily preclude the use of this or other alternative lipids in largemouth bass feeds.

Although no dietary effects were noted for various hematological parameters and measures of nonspecific immunocompetence, Atlantic salmon fed diets containing a blend of poultry fat and canola oil as a partial substitute for anchovy oil demonstrated a marginally reduced response to vaccination with Listonella anguillarum ${ }^{[64]}$. The authors suggested reduced dietary availability of $\mathrm{C}_{20}$ PUFA substrates may have limited eicosanoid production and thus affected the post-vaccination inflammatory response. Although a subsequent disease challenge was not conducted to determine whether these differences in clinical measures would give rise to differences in resistance to $L$. anguillarum, the authors concluded that the fish fed the alternative lipid-based feeds did not show any clear signs of impaired immunocompetence. Channel catfish fed beef tallow solely or blended with menhaden fish and soybean oils exhibited elevated hematocrit, but reduced numbers of circulating leucocytes (total) and thrombocytes ${ }^{[65]}$. The fish fed beef tallow also demonstrated reduced performance in an erythrocyte fragility test, likely resulting from altered red blood cell membrane composition. Although Klinger and colleagues ${ }^{[65]}$ observed that dietary lipid source could influence immunological status of channel 
catfish, they ultimately concluded that a $100 \%$ fish oil based formulation was not necessary.

Generally, the immunological effects of implementing rendered fats in aquafeeds, when observed, appear to be minor. Unfortunately, there is a dearth of disease challenge studies addressing the cumulative immunological effects of dietary lipid. In fact, we are aware of only a single recent study which employed a disease challenge to test the effects of rendered fat on practical disease resistance. In this study, Nile tilapia reared on feeds containing beef tallow as the sole dietary lipid source exhibited impaired production performance, reduced serum lysozyme and complement activities and significantly lower survival following experimental challenge with Streptococcus iniae ${ }^{[32]}$. However, these fish were exhibited moderate anorexia and significantly reduced survival prior to the disease challenge. These fish were likely immunocompromised as a result of generally poor nutrition, not as a specific consequence of feeding beef tallow. This conclusion is supported by the fact that equivalent immunocompetence was observed among normorexic tilapia fed beef tallow as an equalparts blend with other oils. Although reduced feed intake is certainly problematic from a variety of perspectives, use of beef tallow in this study does not appear to have had a direct negative effect on immunocompetence and disease resistance.

Dietary lipid source may affect an assortment of other physiological processes and response criteria as well, though the effect of dietary supplementation with rendered fats is apparently minimal. For example, the reproductive performance of fishes is known to be influenced by maternal lipid nutrition, however, replacing fish oil with poultry fat in feeds for rosy red fathead minnows Pimephales promelas had no effect on egg size, percent hatch, or larval size ${ }^{[66]}$. Following a crowding stress challenge, golden shiners exhibit a classical cortisol response, but magnitude and timecourse of this response was similar among fish raised on poultry fat or menhaden fish oil-based feeds ${ }^{[67]}$. Similarly, replacing dietary menhaden fish oil with poultry fat had no effect on reproductive performance of channel catfish ${ }^{[68]}$. Atlantic salmon fed a lard-based diet had a small but significant effect on circulating levels of astaxanthin, suggesting greater fillet pigmentation could be achieved by including lard in salmonid feeds ${ }^{[69]}$. Presumably astaxanthin levels increased in the bloodstream because the greater dietary levels of SFA and MUFA enhanced intestinal uptake of this fat-soluble pigment. Hepatic activity of carnitine palmitoyltransferase-I, an enzyme associated with shuttling of LC-PUFA into $\beta$-oxidation for energy production, was significantly reduced among brown trout reared on pork lard-, but not poultry-fat-based feeds ${ }^{[70]}$. Though this may suggest reduced fatty acid catabolism and perhaps active sparing of LC-PUFA, these changes did not translate into altered growth performance or conservation of tissue levels of LCPUFA. Atlantic salmon fed a predominantly poultry fatbased diet were significantly outperformed by those reared on an anchovy oil-based feed in an exhaustive swimming trial, but in a repeat trial with the same individuals, no difference in critical swimming speed was observed $^{[71]}$. In a follow-up study, Wilson et al. ${ }^{[72]}$ observed the swimming performance and cardiovascular capacity of Atlantic salmon fed anchovy or poultry-derived lipids and found no difference between the dietary treatments.

Effects on tissue composition and quality: The compositional plasticity of fish tissues with respect to fatty acid profile has been well-documented in a wide range of taxa ${ }^{[29]}$. Although differences in fatty acid uptake, trafficking and utilization give rise to minor differences between dietary and tissue profiles, composition is largely driven by fatty acid intake. Given that most rendered lipids are comprised predominantly of SFA and MUFA, one can expect tissue levels of these fatty acids to increase among fish raised on feeds containing tallows, lards and greases. These changes have been observed in a variety of species and studies.

Tissue proximate composition of grass carp ${ }^{[30]}$ and white sturgeon ${ }^{[73]}$ did not differ between fish fed fish oil and pork lard-or poultry fat-based feeds, but in both studies, fillet fatty acid profile changed to reflect increased intake of SFA and MUFA. Similar effects were observed in Atlantic salmon fed diets containing increasing amounts of a 1:1 blend of canola oil and poultry fat, though fillets did not become significantly enriched with SFA as the feeds were relatively consistent in terms of SFA content ${ }^{[74]}$. Monounsaturated fatty acids also became enriched within the fillet lipid of brown trout fed poultry fat or pork lard, but minor differences in dietary SFA were not reflected within the fillet profile ${ }^{[75]}$.

Carcass proximate composition of rainbow trout was unaffected by replacing $50 \%$ of dietary fish oil with beef tallow, however, the triglycerol profile of the tallow-fed fish reflected a substantial increase in 18:1n9 intake ${ }^{[36]}$. Phospholipid profile was similarly affected, but in a less dramatic fashion, underscoring the strong preference of this lipid class for certain fatty acid chain lengths and levels of desaturation which typically results in a somewhat conserved fatty acid profile. 
Tissue fatty acid composition was similarly affected in surubim $^{[76,77]}$ and white sturgeon ${ }^{[78]}$ fed pork lard-based feeds: Substantial increases in SFA and MUFA were observed in neutral and/or total lipid, but these differences were somewhat attenuated in the polar lipid fraction. Conversely, feeding beef tallow to red drum had the opposite effect: Neutral and polar lipid became enriched with MUFA among tallow-fed fish, but the effect was most overt within the polar fraction ${ }^{[79]}$. It appears that if the fatty acids preferred for incorporation into phospholipid are available, composition can change rapidly within the lipid class, whereas if these fatty acids are not available, composition will be resistant to dietary modification ${ }^{[80]}$.

The concept of selective fatty acid metabolism and preferential inclusion of certain fatty acids within different lipid classes may hold special relevance for the use of rendered lipids in aquafeeds. As previously noted, dietary lipid composition will influence tissue composition and, in turn, the nutritional value of the resultant fillets to the human consumer. Although alternative lipids, including rendered fats, can be readily incorporated into aquafeeds, the resultant seafood products will contain less of the beneficial LCPUFA. To balance the conflicting demands to reduce reliance on marine-derived lipids while maintaining product quality, aquaculture nutritionists have begun investigating the use of finishing feeds to compensate for the effects of alternative lipids on fillet fatty acid profile $^{[81-92]}$. In these strategies, fish are raised on a low LC-PUFA content, alternative lipid based grow-out feed for a majority of the production cycle and then are switched to a high LC-PUFA content, fish oil-based finishing feed to modify fillet fatty acid profile immediately prior to harvest. These strategies have proven effective in significantly altering fillet composition in as little as 4 weeks ${ }^{[93]}$. However, the composition of the grow-out feed, i.e., the alternative lipid source used, can affect finishing success ${ }^{[80,93]}$. In these studies, grow-out feeds rich in SFA and MUFA (provided by coconut oil or poultry fat) yielded the best results in terms of final fillet levels of EPA, DHA and total LC-PUFA. These results suggest rendered fats, as sources of SFA and MUFA, would be particularly appropriate for use during the pre-finishing grow-out period. Further research addressing the use of rendered lipids in context of finishing strategies is certainly warranted.

Manipulations of dietary lipid and fillet fatty acid profile may impact product organoleptic profile and sensory quality. Fillet texture, color, odor, flavor and shelf-life may be influenced by dietary lipid content, fatty acid composition and the presence (or absence) of lipid soluble pigments. As was noted for immunological effects, though use of rendered fats in aquafeeds may influence production quality and consumer acceptance, in practice, the magnitude of these effects appears to be minimal. For example, feeding pork lard or poultry fat to brown trout affected the total amount and profile of volatile flavor compounds in the resultant fillets ${ }^{[70]}$, but these differences were not detected by consumers in a subsequent sensory analysis. Trained panel members noted no differences in the color or odor of fresh product and found the color, flavor and texture of cooked fillets to be equivalent ${ }^{[70]}$. Although consumerbased assessments of fillet color were slightly affected by feeding poultry fat-based diets to rainbow trout (consumers described the fillets as "darker" and "more brown" than fillets from fish oil-fed fish), analytical assessments of fillet color (tristimulus color test) did not reveal a significant effect of dietary lipid source ${ }^{[94]}$. Dietary lipid source did affect shelf-life in this study, but fillets from the poultry fat-fed group exhibited lower levels of TBARS (reduced rancidity) throughout the storage period. Ultimately, Liu et al. ${ }^{[94]}$ concluded that the use of poultry fat had little meaningful influence on rainbow trout fillet quality or consumer acceptance.

Future of rendered products in aquafeeds: Based on the attributes of rendered animal fats, the acceptance and successful utilization of these products by fishes and the economics of aquaculture, the future for rendered animal fats in aquafeeds looks particularly bright. Rendered animal byproducts are the largest potential source of animal-derived feedstocks for the aquaculture industry and in 2000, Tacon described rendered products as "a necessity in aquafeeds for the new millennium" "[95]. This statement appears to have been prescient: As of 2002, roughly 300,000 MT of non-marine animal protein meals were used annually in aquafeeds and this share is expected to grow rapidly ${ }^{[96]}$. Perhaps the biggest issue facing the use of rendered animal products in aquafeeds is public concern over the safety of feeding animal-derived feedstuffs to livestock intended for human consumption. But as we have described previously, these issues are not associated with rendered fats per se and extensive preventative measures have been implemented in the production, import/export and use of rendered animal products to avoid issues of microbiological or other contaminants entering the human food supply. Further, the risk, both real and perceived, of transmitting pathogenic material via feeding of animal processing byproducts is minimized when the phylogenetic distinction between the source animals and the target livestock is large. 
Thus, the feeding of terrestrial rendered products to fish (and likewise, the feeding of rendered fishery products to terrestrial livestock) is considered quite safe. Although the use of fish meal and fish oil in aquafeeds has been considered benign in terms of disease transmission, a new type of rendered fishery product, i.e., derived from mortalities and processing wastes from the aquaculture industry and the potential safety issues they may pose have not been addressed. One can argue that the fish species being fed traditional marine reduction fishery products (salmonids and basses) are still quite distinct from the source animals (anchoveta and menhadens). If the fish meal and oil are being derived from, for example, catfish or salmon processing wastes, the issue becomes more complex. Although catfish oil is currently being used in feeds for catfish (US) and salmon oil is being fed to salmon (Chile) without biological consequences or public backlash, the possible risk for disease transmission and negative perception should not be dismissed out of hand. Disposal of aquaculture trimmings and offal is an increasingly important issue and certainly this growing source of feedstuffs should be used to maximal advantage. However, the risks of "intraspecies recycling" should be evaluated or, ideally, avoided altogether ${ }^{[6]}$.

\section{CONCLUSION}

In closing, it is very likely that the current use of rendered animal fats in aquafeeds can be increased. However, further research will be needed to support expanded applications in aquafeeds and to avoid pitfalls that may arise when nutritionists begin to "push the envelope' with rendered lipids in the feeding of fishes.

\section{REFERENCES}

1. FAO., 2008. The state of World Fisheries and Aquaculture. Food and Agriculture Organization of the United Nations, Rome, Italy, ISBN: 978-92-5106029-2.

2. Naylor, R.L., R.J. Goldburg, J.H. Primavera, N. Kautsky and M.C.M. Beveridge et al., 2000. Effect of aquaculture on world fish supplies. Nature, 405: 1017-1024. DOI: 10.1038/35016500

3. Foran, J.A., R.A. Hites, D.O. Carpenter and M.C. Hamilton, 2004. A survey of metals in tissues of farmed Atlantic and wild Pacific salmon. Environ. Toxicol. Chem., 23: 2108-2110. DOI: $10.1897 / 04-72$
4. Hites, R.A., J.A. Foran, D.O. Carpenter, M.C. Hamilton and B.A. Knuth et al., 2004. Global assessment of organic contaminants in farmed salmon. Science, 303: 226-229. DOI: 10.1126/science. 1091447

5. Foran, J.A., D.O. Carpenter, M.C. Hamilton, B.A. Knuth and S.J. Schwager, 2005. Risk-based consumption advice for farmed Atlantic and wild Pacific salmon contaminated with dioxins and dioxin-like compounds. Environ. Health Perspect., 113: 552-556. DOI: $10.1289 /$ ehp.7626

6. Tacon, A.G.J. and M. Metian, 2008. Global overview on the use of fish meal and fish oil in industrial compounded aquafeeds: Trends and future prospects. Aquaculture, 285:146-158. DOI: 10.1016/j.aquaculture.2008.08.015

7. Bureau, D.P., J. Gibson and A. El-Mowafi, 2002. Review: Use of Animal Fats in Aquaculture Feeds. In: Advances in Aquatic Nutrition VI, Proceedings of the 6th Symposium, L.E. Cruz-Suárez, D. Ricque-Marie, M. Tapia-Salazar, M.G. GaxiolaCortés and N. Simoes (Eds.). International Symposium on Aquatic Nutrition, Cancún, Quintana Roo, México, pp: 487-504.

8. Sathivel, S., W. Prinyawiwatkul, C.C. Grimm, J.M. King and S. Lloyd, 2002. FA composition of crude oil recovered from catfish viscera. J. AOCS., 79: 989-992. DOI: $10.1007 / \mathrm{s} 11746-002-0592-5$

9. Meeker, D.L., 2006. Essential rendering: All about the animal by-products industry. National Renderers Association, Alexandria, VA., USA., ISBN: 0-9654660-3-5, pp: 314.

10. Gavin, A.M., 1978. Edible oil deodorization. J. AOCS., 55: 783-791. DOI: 10.1007/BF02682649.

11. NRC., 1993. Nutrient Requirements of Fish. National Academy Press, 1st Edn., Washington, DC., USA., ISBN:0-309-04891-5, pp: 128.

12. Gray, J.I., 1978. Measurement of lipid oxidation: A review. J. AOCS., 55: 539-546. DOI: 10.1007/BF02668066

13. DeRouchey, J.M., J.D. Hancok, R.H. Hines, C.A. Maloney and D.J. Lee et al., 2004. Effects of rancidity and free fatty acids in choice white grease on growth performance and nutrient digestibility in weanling pigs. J. Anim. Sci., 82: 2937-2944, http://jas.fass.org/cgi/content/full/82/10/2937

14. Gopalakrishna, A.G. and J.V. Prabhakar, 1983. Effect of water activity on autoxidation of raw peanut oil. J. AOCS., 60: 968-970. DOI: DOI: 10.1007/BF02660209

15. Stansby, M.E., 1990. Deterioration. In: Fish Oils in Nutrition, Stansby M.E. (Ed.). Van Nostrand Reinhold, New York, USA., ISBN: 0-442-23748-0, pp: 313. 
16. Hata, K. and T. Kaneda, 1980. Effect of autoxidized oil on carp. Bull. Jap. Soc. Sci. Fish, 46: 997-1000.

17. Baker, R.T.M. and S.J. Davies, 1996. Oxidative nutritional stress associated with feeding rancid oils to African catfish, Clarias gariepinus (Burchell) and the protective role of $\alpha$-tocopherol. Aquac. Res., 27: 795-803. DOI: 10.1111/j.13652109.1996.tb01238.x

18. Huang, C.H. and S.L. Huang, 2004. Effect of dietary vitamin $\mathrm{E}$ on growth, tissue lipid peroxidation and liver glutathione level of juvenile hybrid tilapia, Oreochromis niloticus x O. aureus, fed oxidized oil. Aquaculture, 237: 381-389. DOI: 10.1016/j.aquaculture.2004.04.002

19. Post, G.W., 1992. Nutrition and Nutritional Disease of Salmonids. In: Fish Medicine, Stoskopf, M.K. (Ed.). W.B. Saunders, Philadelphia, USA., ISBN:0721626297, pp: 902.

20. Obach, A. and F. Baudin Laurencin, 1992. Effects of dietary oxidized fish oil and deficiency of antioxidants on the immune response of turbot, Scophthalmus maximus. Aquaculture, 107: 221-228. DOI: 10.1016/0044-8486(92)90070-2

21. Trushenski, J.T. and C.C.Kohler, 2006. Evaluation of natural-source vitamin E, RRR-alpha tocopheryl acetate, as a micronutrient in sunshine bass feeds. N. Am. J. Aquac., 68: 186-191. DOI: 10.1577/A05-011.1

22. Trushenski, J.T. and C.C. Kohler, 2008. Influence of vitamin $\mathrm{E}$ source and dietary supplementation level on production performance of sunshine bass Morone chrysops $+\times M$. saxatilis $\hat{\partial}$, fillet tocopherol content and immunocompetency during stress and bacterial challenge. J. World Aquac. Soc., 39: 454-466. DOI: 10.1111/j.17497345.2008.00179.x

23. Yanishlieva, N.V. and E.M. Marinova, 2001. Stabilization of edible oils with natural antioxidants. Eur. J. Lipid Sci. Technol., 103: 752-767. DOI: $10.1002 / 1438-$ 9312(200111)103:11<752::AID-EJLT752>3.0.CO;2-0

24. Codex Alimentarius. Section 3. Codex standard for fats and oils from animal sources. 1999. Codex Standard for Named Animal Fats (CODEX-STAN 211-1999). FAO (Food and Agricultural Organization) of the United Nations, Rome, Italy, ISBN: 92-5-104682-4.

25. Sapkota, A.R., L.Y. Lefferts, S. McKenzie and P. Walker, 2007. What do we feed to foodproduction animals? A review of animal feed ingredients and their potential impacts on human health. Environ. Health Perspect., 115: 663-670. DOI: 10.1289/ehp.9760
26. Winters, D., D. Cleverly, M. Lorber, K. Meier and A. Dupuy, 1996. Coplanar Polychlorinated Biphenyls (PCBs) in a national sample of beef in the United States: Preliminary results. Organohalogen Comp., 27: 386-390. http://www.epa.gov/ncea/pdfs/pcbbeef.pdf

27. Ferrario, J., C. Byrne, M. Lorber, P. Saunders and W. Leese et al., 1997. A statistical survey of dioxin-like compounds in United States poultry fat. Organohalogen Comp., 32: 245-251. http://www.epa.gov/ncea/pdfs/poultry.pdf

28. Lorber, M., P. Saunders, J. Ferrario, W. Leese and D. Winters et al., 1997. A statistical survey of dioxin-like compounds in United States pork fat. Organohalogen Comp., 32: 238-244. http://www.epa.gov/ncea/pdfs/pork.pdf

29. Turchini, G.M., B.E. Torstensen and W.K. Ng, 2009. Fish oil replacement in finfish nutrition. Rev. Aquac., 1: 10-57. DOI: 10.1111/j.17535131.2008.01001.x

30. Du, Z.Y., P. Clouet, L.M. Huang, P. Degrace and W.H. Zheng et al., 2008. Utilization of different dietary lipid source at high level in herbivorous grass carp (Ctenopharyngodon idella): Mechanism related to hepatic fatty acid oxidation. Aquac. Nutr., 14: 77-92. DOI: 10.1111/j.13652095.2007.00507.x

31. Yilmaz, E. and E. Genc, 2006. Effects of alternative dietary lipid source (soy-acid oil and yellow grease) on growth and hepatic lipidosis of common carp (Cyprinus carpio) fingerling: A preliminary study. Turk. J. Fish Aquat. Sci., 6: 37-42.

32. Yildirim-Aksoy, M., C. Lim, D.A. Davis, R. Shelby and P.H. Klesius, 2007. Influence of dietary lipid sources on the growth performance, immune response and resistance to Nile tilapia, Oreochromis niloticus, to Streptococcus iniae challenge. J. Applied Aquac., 19: 29-49. DOI: 10.1300/J028v19n02_02

33. Fracalossi, D.M. and R.T. Lovell, 1994. Dietary lipid sources influence responses of channel catfish (Ictalurus punctatus) to challenge with the pathogen Edwardsiella ictaluri. Aquaculture, 119: 287-298. DOI: 10.1016/0044-8486(94)90183$\mathrm{X}$

34. Fracalossi, D.M., M.C. Craig-Schmidt and R.T. Lovell, 1994. Effect of dietary lipid sources on production of leukotriene B by head kidney of channel catfish held at different water temperatures. J. Aquatic Anim. Health 6: 242-250. DOI: $10.1577 / 1548-$ 8667(1994)006<0242:EODLSO>2.3.CO;2 
35. Lingenfelser, J.T., V.S. Blazer and J. Gay, 1995. Influence of fish oils in production catfish feeds on selected disease resistance factors. J. Applied Aquac., 5: 37-48. DOI: 10.1300/J028v05n02_04

36. Bureau, D.P., K. Hua and A.M. Harris, 2008. Growth, energy utilization, carcass quality and immune function of rainbow trout, Oncorhynchus mykiss. J. World Aquac. Soc., 39: 1-20. DOI: 10.1111/j.1749-7345.2007.00146.x

37. Bransden, M.P., C.G. Carter and P.D. Nichols, 2003. Replacement of fish oil with sunflower oil in feeds for Atlantic salmon (Salmo salar L.): Effect on growth performance, tissue fatty acid composition and disease resistance. Comp. Biochem. Phys. B., 135: 611-625. DOI: 10.1016/S1096-4959(03)00143-X

38. Oxley, A., A.S. Bogevik, R.J. Henderson, R. Waagbǿ, D.R. Tocher and R.E. Olsen, 2009. Digestibility of Calanus finmarchicus wax esters in Atlantic salmon (Salmo salar) freshwater presmolts and seawater postsmolts maintained at constract water temperature. Aquac. Nutr., 15: 459-469. DOI: 10.1111/j.1365-2095.2008.00611.x

39. Koven, W.M., R.J. Henderson and J.R. Sargent, 1997. Lipid digestion in turbot (Scophthalmus maximus) in-vivo and in-vitro studies of the lipolytic activity in various segments of the digestive tract. Aquaculture, 151: 155-171. DOI: 10.1016/S00448486(96)01484-6

40. Tocher, D.R., E.Å. Bendiksen, P.J. Campbell and J.G. Bell, 2008. The role of phospholipids in nutrition and metabolism of teleost fish. Aquaculture, 280: 21-34. DOI: 10.1016/j.aquaculture.2008.04.034

41. Peréz, J.A., C. Rodríguez and R.J. Henderson, 1999. The uptake and esterification of radiolabelled fatty acids by enterocytes isolated from rainbow trout (Oncorhynchus mykiss). Fish Phys. Biochem., 20: 125-134. DOI: 10.1023/A:1007795516689.

42. Oxley, A., D.R. Tocher, B.E. Torstensen and R.E. Olsen, 2005. Fatty acid utilization and metabolism in caecal enterocytes of rainbow trout (Oncorhynchus mykiss) fed dietary fish or copepod oil. Biochim. Biophys. Acta, 1737: 119-129. DOI: 10.1016/j.bbalip.2005.09.008

43. Olsen, R.E., R.J. Henderson and E. Ringǿ, 1998. The digestion and selective absorption of dietary fatty acids in Arctic charr, Salvelinus alpines. Aquac. Nutr., 4: 13-21. DOI: 10.1046/j.13652095.1998.00099.x
44. Ng, W-K., T. Sigholt and J.G. Bell, 2004. The influence of environmental temperature on the apparent nutrient and fatty acid digestibility in Atlantic salmon (Salmo salar L.) fed finishing diets containing different blends of fish oil, rapeseed oil and palm oil. Aquac. Res., 35: 1228-1237. DOI: 10.1111/j.1365-2109.2004.01131.x

45. Bahurmiz, O.M. and W.K. Ng, 2007. Effects of dietary palm oil source on growth, tissue fatty acid composition and nutrient digestibility of red hybrid tilapia, Oreochromis sp., raised from stocking to marketable size. Aquaculture, 262: 382-392. DOI: 10.1016/j.aquaculture.2006.11.023.

46. Caballero, M.J., A. Obach, G. Rosenlund, D. Montero, M. Gisvold and M.S. Izquierdo, 2002. Impact of different dietary lipid sources on growth, lipid digestibility, tissue fatty acid composition and histology of rainbow trout, Oncorhynchus mykiss. Aquaculture, 214: 253-271. DOI: 10.1016/S00448486(01)00852-3

47. Hansen, J.O., G.M. Berge, M. Hillestad, Å. Krogdahl and T.F. Galloway et al., 2008. Apparent digestion and apparent retention of lipid and fatty acids in Altantic cod (Gadus morhua) fed increasing dietary lipid levels. Aquaculture, 284: 159-166. DOI: 10.1016/j.aquaculture.2008.07.043

48. Turchini, G.M., T. Mentasti, F. Caprino, I. Giani and S. Panseri et al., 2005. The relative absorption of fatty acids in brown trout (Salmo trutta) fed a commercial extruded pellet coated with different lipid sources. Ital. J. Anim. Sci., 4: 241-252. http://www.aspajournal.it/abstact/03_2005/IJAS03_05-Turchini.pdf

49. Francis, D.S., G.M. Turchini, P.L. Jones and S.S. De Silva, 2007. Effects of fish oil substitution with a mix blend vegetable oil on nutrient digestibility in Murray cod, Maccullochella peelii peelii. Aquaculture, 269: 447-455. DOI: 10.1016/j.aquaculture.2007.05.021

50. Henderson, R.J. and J.R. Sargent, 1985. Chainlength specificities of mitochondrial and peroxisomal beta-oxidation of fatty acids in livers of rainbow trout (Salmo gairdneri). Comp. Biochem. Phys. B., 82: 79-85. PMID: 4053576

51. Kiessling, K.H. and A. Kiessling, 1993. Selective utilization of fatty acids in rainbow trout (Oncorhynchus mykiss Walbaum) red muscle mitochondria. Can. J. Zool., 71: 248-251. DOI: 10.1139/z93-035

52. Henderson, R.J., 1996. Fatty acid metabolism in freshwater fish with particular reference to polyunsaturated fatty acids. Arch. Tierernahr, 49: 5-22. PMID: 8766969 
53. Frǿyland, L., O. Lie and R.K. Berge, 2000. Mitochondrial and peroxisomal $\beta$-oxidation capacities in various tissues from Atlantic salmon Salmo salar. Aquac. Nutr., 6: 85-89. DOI: 10.1046/j.1365-2095.2000.00130.x

54. Crockett, E.L. and B.D. Sidell, 1993. Substrate selectivities differ for hepatic mitochondrial and peroxisomal $\beta$-oxidation in an Antarctic fish, Notothenia gibberifrons. Biochem. J., 289: 427-433. PMCID: PMC1132185

55. Torstensen, B.E., L. Frǿyland and Ǿ. Lie, 2004. Replacing dietary fish oil with increasing levels of rapeseed oil and olive oil-effects on Atlantic salmon (Salmo salar L.) tissue and lipoprotein lipid composition and lipogenic enzyme activities. Aquac. Nutr., 10: 175-192. DOI: 10.1111/j.13652095.2004.00289.x

56. Montero, D., T. Kalinowski, A. Obach, L. Robaina, L. Tort et al., 2003. Vegetable lipid sources for gilthead seabream (Sparus aurata): Effects on fish health. Aquaculture, 225: 353-370. DOI: 10.1016/S0044-8486(03)00301-6

57. Bell, J.G. and J.R. Sargent, 2003. Arachidonic acid in aquaculture feeds: Current status and future opportunities. Aquaculture, 218: 491-499. DOI: 10.1016/S0044-8486(02)00370-8

58. Farndale, B.M., J.G. Bell, M.P. Bruce, N.R. Bromage and F. Oyen et al., 1999. Dietary lipid composition affects blood leucocyte fatty acid compositions and plasma eicosanoid concentrations in European sea bass (Dicentrarchus labrax). Aquaculture, 179: $\quad 335-350$. DOI: $10.1016 /$ S00448486(99)00169-6

59. Bell, J.G., I. Ashton, C.J. Secombes, B.R. Weitzel, J.R. Dick and J.R. Sargent, 1996. Dietary lipid affects phospholipid fatty acid compositions, eicosanoid production and immune function in Atlantic salmon (Salmo salar). Prostaglandins, Leukotrienes Essent. Fatty Acids, 54: 173-182. DOI: 10.1016/S0952-3278(96)90013-7

60. Thompson, K.D., M.F. Tatner and R.J. Henderson, 1996. Effects of dietary (n-3) and (n-6) polyunsaturated fatty acid ratio on the immune response of Atlantic salmon, Salmo salar L. Aquac. Nutr., 2: 21-31. DOI: 10.1111/j.13652095.1996.tb00004.x.

61. Mourente, G., J.E. Good, K.D. Thompson and J.G. Bell, 2007. Effects of partial substitution of dietary fish oil with blends of vegetable oils, on blood leucocyte fatty acid compositions, immune function and histology in European sea bass (Dicentrarchus labrax L.). Br. J. Nutr., 98: 770-779. DOI: $10.1017 /$ S000711450773461X
62. Babalola, T.O.O., M.A. Adebayo, D.F. Apata and J.S. Omotosho, 2009. Effect of dietary alternative lipid sources on haematological parameters and serum constituents of Heterobranchus longifilis fingerlings. Trop. Anim. Health Prod., 41: 371-377. DOI: $10.1007 / \mathrm{s} 11250-008-9199-1$

63. Subhadra, B., R. Lochmann, S. Rawles and R. Chen, 2006. Effect of dietary lipid source on the growth, tissue composition and hematological parameters of largemouth bass (Micropterus salmoides). Aquaculture, 255: 210-222. DOI: 10.1016/j.aquaculture.2005.11.043

64. Balfry, S.K., J. Oakes, M. Rowshandeli, G. Deacon, B.J. Skura and D.A. Higgs, 2006. Efficacy of an equal blend of canola oil and poultry fat as an alternative dietary lipid source for Atlantic salmon (Salmo salar L.) in seawater. II: Effects on haematology and immunocompetence. Aquac. Res., 37: 192-199. DOI: 10.1111/j.13652109.2005.01421.x

65. Klinger, R.C., V.S. Blazer and C. Echevarria, 1996. Effects of dieary lipid on the hematology of channel catfish, Ictalurus punctatus. Aquaculture, 147: 225-233. DOI: $10.1016 /$ S00448486(96)01410-X

66. Kumaran, S., R. Lochmann, N. Stone, A. Kachowski and Y.W. Lee, 2007. Effects of diets with or without menhaden fish meal and oil on egg size, hatchability and fry size for rosy red fathead minnow. N. Am. J. Aquac., 69: 419-428. DOI: 10.1577/A06-089.1

67. Lochmann, R.T., K.B. Davis and B.A. Simco, 2002. Cortisol response of golden shiners (Notemigonus crysoleucas) fed diets differing in lipid content. Fish Phys. Biochem., 27: 29-34. DOI: 10.1023/B:FISH.0000021772.86442.08

68. Sink, T.D. and R.T. Lochmann, 2008. Effects of dietary lipid source and concentration on channel catfish (Ictalurus punctatus) egg biochemical composition, egg and fry production and egg and fry quality. Aquaculture, 283: 68-76. DOI: 10.1016/j.aquaculture.2008.07.024

69. Olsen, R.E., A. Kiessling, J.E. Milley, N.W. Ross and S.P. Lall, 2005. Effect of lipid source and bile salts in diet of Atlantic salmon Salmo salar L., on astaxanthin blood levels. Aquaculture, 250: 804-812. DOI: $10.1016 / \mathrm{j}$.aquaculture.2005.03.013

70. Turchini, G.M., T. Mentasti, L. Froyland, E. Orban and F. Caprino et al., 2003. Effects of alternative dietary lipid sources on performance, tissue chemical composition, mitochondrial fatty acid oxidation capabilities and sensory characteristics in brown trout (Salmo trutta L.). Aquaculture, 225: 251-267. DOI: $10.1016 /$ S00448486(03)00294-1 
71. Wagner, G.N., S.K. Balfry, D.A. Higgs, S.P. Lall and A.P. Farrell, 2004. Dietary fatty acid composition affects the repeat swimming performance of Atlantic salmon in seawater. Comp. Biochem. Phys. A., 137: 567-576. DOI: 10.1016/j.cbpb.2003.11.005

72. Wilson, C.M., E.N. Friesen, D.A. Higgs and A.P. Farrell, 2007. The effect of dietary lipid and protein source on the swimming performance, recovery ability and oxygen consumption of Atlantic salmon (Salmo salar). Aquaculture, 273: 687-699. DOI: 10.1016/j.aquaculture.2007.10.027

73. Xu, R., S.S.O. Hung and J.B. German, 1993. White sturgeon tissue fatty acid compositions are affected by dietary lipids. J. Nutr., 123: 1685-1692.

74. Higgs, D.A., S.K. Balfry, J.D. Oakes, M. Rowshandeli, B.J. Skura and G. Deacon, 2006. Efficacy of an equal blend of canola oil and poultry fat as an alternate dietary lipid source for Atlantic salmon (Salmo salar L.) in sea water. I: Effects on growth performance and whole body and fillet proximate and lipid composition. Aquac. Res., 37: 180-191. DOI: $10.1111 / \mathrm{j} .1365-$ 2109.2005.01420.x

75. Turchini, G.M., T. Mentasti, F. Caprino, S. Panseri, V.M. Moretti and F. Valfré, 2004. Effects of dietary lipid sources on flavor volatile compounds of brown trout (Salmo trutta L.) fillet. J. Applied Ichthyol., 20: 71-75. DOI: 10.1046/j.01758659.2003.00522.x

76. Martino, R.C., J.E.P. Cyrino, L. Portz and L.C. Trugo, 2002. Performance and fatty acid composition of surubim (Pseudoplatystoma coruscans) fed diets with animal and plant lipids. Aquaculture, 209: 233-246. DOI: 10.1016/S00448486(01)00847-X

77. Martino, R.C. and L.C. Trugo, 2003. Use of white fat as a replacement for squid liver oil in practical diets for surubim Pseudoplatystoma coruscans. J. World Aquaculture Soc., 34: 192-202. DOI: 10.1111/j.1749-7345.2003.tb00056.x

78. Xu, R., S.S.O. Hung and J.B. German, 1996. Effects of dietary lipids on the fatty acid composition of triglycerides and phospholipids in tissues of white sturgeon. Aquac. Nutr., 2: 101-109. DOI: 10.1111/j.1365-2095.1996.tb00016.x

79. Craig, S.R. and D.M. Gatlin, 1995. Coconut oil and beef tallow, but not tricaprylin, can replace menhaden oil in the diet of red drum (Sciaenops ocellatus) without adversely affecting growth or fatty acid composition. J. Nutr., 125: 3041-3048.
80. Trushenski, J.T., H.A. Lewis and C.C. Kohler, 2008. Fatty acid profile of sunshine bass: II. Profile change differs among fillet lipid classes. Lipids, 43: 643-653. DOI: 10.1007/s11745-0083190-5

81. Regost, C., J. Arzel, J. Robin, G. Rosenlund and S.J. Kaushik, 2003. Total replacement of fish oil by soybean or linseed oil with a return to fish oil in turbot (Psetta maxima). 1. Growth performance, flesh fatty acid profile and lipid metabolism. Aquaculture, 217: 465-482. DOI: 10.1016/S00448486(02)00259-4

82. Bell, J.G., D.R. Tocher, R.J. Henderson, J.R. Dick and V.O. Crampton, 2003. Altered fatty acid compositions in Atlantic salmon (Salmo salar) fed diets containing linseed and rapeseed oils can be partially restored by a subsequent fish oil finishing diet. J. Nutr., 133: 2793-2801. PMID: 12949367.

83. Bell, J.G., R.J. Henderson, D.R. Tocher and J.R. Sargent, 2004. Replacement of dietary fish oil with increasing levels of linseed oil: Modification of flesh fatty acid compositions in Atlantic salmon (Salmo salar) using a fish oil finishing diet. Lipids, 39: 223-232. DOI: 10.1007/s11745-004-1223-5

84. Torstensen, B.E., L. Frǿyland, R. Ǿrnsrud and O. Lie, 2004. Tailoring of a cardioprotective muscle fatty acid composition of Atlantic salmon (Salmo salar) fed vegetable oils. Food Chem., 87: 567-580. DOI: 10.1016/j.foodchem.2004.01.009

85. Bell, J.G., F. McGhee, J.R. Dick and D.R. Tocher, 2005. Dioxin and dioxin-like polychlorinated biphenyls (PCBs) in Scottish farmed salmon (Salmo salar): Effects of replacement of dietary marine fish oil with vegetable oils. Aquaculture, 243: 305-314. DOI: 10.1016/j.aquaculture.2004.10.016.

86. Izquierdo, M.S., D. Montero, L. Robaina, M.J. Caballero, G. Rosenlund and R. Ginéz, 2005. Alterations in fillet fatty acid profile and flesh quality in gilthead seabream (Sparus aurata) fed vegetable oils for a long term period. Recovery of fatty acid profiles by fish oil feeding. Aquaculture, 250: 431-444. DOI: 10.1016/j.aquaculture.2004.12.001

87. Torstensen, B.E., J.G. Bell, R. Rosenlund, R.J. Henderson and I.E. Graff et al., 2005. Tailoring of Atlantic salmon (Salmo salar L.) flesh lipid composition and sensory quality by replacing fish oil with a vegetable oil blend. J. Agric. Food Chem., 53: 10166-10178. DOI: 10.1021/jf051308i 
88. Lane, R.L., J.T. Trushenski and C.C. Kohler, 2006. Modification of fillet composition and evidence of differential fatty acid turnover in sunshine bass Morone chrysops $\times$ M. saxatilis following change in dietary lipid source. Lipids, 41: 1029-1038. DOI: $10.1007 / \mathrm{s} 11745-006-5053-2$

89. Turchini, G.M., D.S. Francis and S.S. De Silva, 2006. Modification of tissue fatty acid composition in Murray cod (Maccullochella peelii peelii, Mitchell) resulting from a shift from vegetable oil diets to a fish oil diet. Aquac. Res., 37: 570-585. DOI: $10.1111 / \mathrm{j} .1365-2109.2006 .01465 . \mathrm{x}$

90. Jobling, M., O. Leknes, B.S. Saether and E. Bendiksen, 2008. Lipid and fatty acid dynamics in Atlantic cod, Gadus morhua, tissues: Influence of dietary lipid concentrations and feed oil sources. Aquaculture, 281: 87-94. DOI: 10.1016/j.aquaculture.2008.05.027

91. Benedito-Palos, L., J.C. Navarro, A. Bermejo-Nogales, A. Saera-Vila, S. Kaushik and J. Pérez-Sánchez, 2009. The time course of fish oil wash-out follows a simple dilution model in gilthead sea bream (Sparus aurata L.) fed grade levels of vegetable oils. Aquaculture, 288: 98-105. DOI: 10.1016/j.aquaculture.2008.11.010

92. Fountoulaki, E., A. Vasilaki, R. Hurtado, K. Grigorakis and I. Karacostas et al., 2009. Fish oil substitution by vegetable oils in commercial diets for gilthead sea bream (Sparus aurata L.); effects on growth performance, flesh quality and fillet fatty acid profile; recovery of fatty acid profiles by a fish oil finishing diet under fluctuating water temperatures. Aquaculture, 289: 317-326. DOI: 10.1016/j.aquaculture.2009.01.023

93. Trushenski, J.T., J. Boesenberg and C.C. Kohler, 2009. Influence of grow-out feed fatty acid composition on finishing success in Nile tilapia. N. Am. J. Aquac., 71: 242-251. DOI: 10.1577/A08051.1

94. Liu, K.K.M., F.T. Barrows, R.W. Hardy and F.M. Dong, 2004. Body composition, growth performance and product quality of rainbow trout (Oncorhynchus mykiss) fed diets containing poultry fat, soybean/corn lecithin, or menhaden oil. Aquaculture, 238: 309-328. DOI: $10.1016 /$ j.aquaculture.2004.03.022

95. Tacon, A.G.J., 2000. Rendered animal by-products: A necessity in aquafeeds for the new millennium. Global Aquac. Advocate, 3: 18-19. http://pdf.gaalliance.org/pdf/gaa-tacon-aug00.pdf

96. FAO., 2004. Protein Sources for the Animal feed Industry. Food and Agriculture Organization of the United Nations, Rome, Italy, ISBN: 92-5-1050120, pp: 25.
97. Li, M.H., D.J. Wise, M.R. Johnson and E.H. Robinson, 1994. Dietary menhaden oil reduced resistance of channel catfish (Ictalurus punctatus) to Edwardsiella ictaluri. Aquaculture, 128: 335-344. DOI: 10.1016/0044-8486(94)90321-2

98. Reigh, R.C. and S.C. Ellis, 2000. Effects of dietary catfish oil, menhaden oil and tallow on production characteristics of pond-raised channel catfish, Ictalurus punctatus. J. Applied Aquac., 10: 53-63. DOI: 10.1300/J028v10n01_06

99. Lochmann, R. and H. Phillips, 1995. Comparison of rice bran oil, poultry fat and cod liver oil as supplemental lipids in feeds for channel catfish and golden shiner. J. Applied Aquacu., 5: 47-55. DOI: 10.1300/J028v05n03_05

100.O'Neal, C.C. and C.C. Kohler, 2008. Effect of replacing menhaden oil with catfish oil on the fatty acid composition of juvenile channel catfish, Ictalurus punctatus. J. World Aquac. Soc., 39: 62-71. DOI: 10.1111/j.1749-7345.2007.00137.x

101.Murai, T., T. Akiyama, T. Watanabe and T. Nose, 1985. Effects of dietary protein and lipid levels on performance and carcass composition of fingerling carp. Bull. Jap. Soc. Sci. Fish, 51: 605-608.

102.Schwarz, F.J., M. Kirchgessner, H. Steinhart and G. Runge, 1988. Influence of different fats with varying additions of alpha-tocopherol acetate on growth and body composition of carp (Cyprinus carpio L.). Aquaculture, 69: 57-67. DOI: 10.1016/00448486(88)90186-X

103.Hoffman, L.C. and J.F. Prinsloo, 1995. The influence of different dietary lipids in the growth and body composition of the African sharptooth catfish, Clarias gariepinus (Burchell). S. Afr. J. Sci., 91: 315-320.

104.Stickney, R.R. and R.B. McGeachin, 1984. Growth, food conversion and survival of fingerling Tilapia aurea fed differing levels of dietary beef tallow. Prog. Fish-Culturist, 46: 102-105. DOI: $10.1577 / 1548$ 8640(1984)46<102:GFCASO>2.0.CO;2

105.Stickney, R.R. and W.A. Wurts, 1986. Growth response of blue tilapias to selected levels of dietary menhaden and catfish oils. Prog. FishCulturist, 48: 107-109. DOI: 10.1577/15488640(1986)48<107:GROBTT>2.0.CO;2

106. Chou, B.S. and S.Y. Shiau, 1999. Both n-6 and n-3 fatty acids are required for maximal growth of juvenile hybrid tilapia. N. Am. J. Aquac., 61: 13-20. DOI: $10.1577 / 1548$ 8454(1999)061<0013:BNANFA>2.0.CO;2 
107.Huang, C.H., M.C. Huang and P.C. Hou, 1998. Effect of dietary lipids on the fatty acid composition and lipid peroxidation in sarcoplasmic reticulum of hybrid tilapia, Oreochromis niloticus $\times$ O. aureus. Comp. Biochem. Phys. B., 120: 331-336. DOI: 10.1016/S0305-0491(98)10022-6

108.Lochmann, R. and S. Kumaran, 2006. Effect of practical diets with animal or vegetable protein sources and poultry oil or menhaden fish oil on adult fathead minnow in tanks. N. Am. J. Aquac., 68: 281-286. DOI: 10.1577/A05-040.1

109.Xue, M., L. Luo, X. Wu, Z. Ren, P. Gao, Y. Yu and G. Pearl, 2006. Effects of six alternative lipid sources on growth and tissue fatty acid composition in Japanese sea bass (Lateolabrax japonicas). Aquaculture, 260: 206-214. DOI: 10.1016/j.aquaculture.2006.05.054

110.Robinette, H.R., J.B. Taylor, D.M. Gatlin and S. Craig, 1997. Effects of dietary catfish and menhaden oils on hybrid striped bass production. Prog. FishCulturist, 59: 261-265. DOI: 10.1577/15488640(1997)059<0261:EODCAM>2.3.CO;2

111.Takeuchi, T., T. Watanabe and C. Ogino, 1978. Use of hydrogenated fish oil and beef tallow as a dietary energy source for carp and rainbow trout. Bull. Jap. Soc. Sci. Fish, 44: 875-881.

112.Greene, D.H.S. and D.P. Selivonchick, 1990. Effects of dietary vegetable, animal and marine lipids on muscle lipid and hematology of rainbow trout (Oncorhynchus mykiss) Aquaculture, 89: 165-182. DOI: 10.1016/0044-8486(90)90308-A

113.Yu, T.C. and R.O. Sinnhuber, 1981. Use of beef tallow as an energy source in coho salmon (Oncorhynchus kisutch) rations. Can. J. Fish Aquatic. Sci., 38: 367-370. DOI: 10.1139/f81-049

114.Dosanjh, B.S., D.A. Higgs, M.D. Plotnikoff, J.R. McBride, J.R. Markert and J.T. Buckley, 1984. Efficacy of canola oil, pork lard and marine oil singly and in combination as supplemental dietary lipid sources for juvenile coho salmon (Oncorhynchus kisutch). Aquaculture, 36: 333-345. DOI: 10.1016/0044-8486(84)90326-0
115.Mugrditchian, D.S., R.W. Hardy and W.T. Iwaoka, 1981. Linseed oil and animal fat as alternative lipid sources in dry diets for Chinook salmon (Oncorhynchus tshawytscha). Aquaculture, 25: 161-172. DOI: 10.1016/0044-8486(81)90178-2

116.Dosanjh, B.S., D.A. Higgs, M.D. Plotnikoff, J.R. Markert and J.T. Buckley, 1988. Preliminary evaluation of canola oil, pork lard and marine lipid singly and in combination as supplemental dietary lipid sources for juvenile fall Chinook salmon (Oncorhynchus tshawytscha). Aquaculture, 68: 325-343. DOI: 10.1016/0044-8486(88)90247-5

117.Hardy, R.W., T.M. Scott and L.W. Harrell, 1987. Replacement of herring oil with menhaden oil, soybean oil, or tallow in the diets of Atlantic salmon raised in marine net-pens. Aquaculture, 65: 267-277. DOI: 10.1016/0044-8486(87)90240-7

118.Bell, J.G., A. Youngson, A.I. Mitchell and C.B. Cowey, 1989. The effect of enhanced intake of linoleic acid on the fatty acid composition of tissue polar lipids of post-smolt Atlantic salmon (Salmo salar). Lipids, 24: 240-242. DOI: 10.1007/BF02535243

119.Rosenlund, G., A. Obach, M.G. Sandberg, H. Standal and K. Tveit, 2001. Effect of alternative lipid sources on long-term growth performance and quality of Atlantic salmon (Salmo salar L.). Aquac. Res., 32: 323-328. DOI: 10.1046/j.1355557x.2001.00025.x 